Illinois State University

ISU ReD: Research and eData

Theses and Dissertations

3-16-2020

\title{
The Polite Abuser: Using Politeness Theory To Examine Emotional
} Abuse

Cimmiaron Alvarez

Illinois State University, cpalvar@ilstu.edu

Follow this and additional works at: https://ir.library.illinoisstate.edu/etd

Part of the Communication Commons

\section{Recommended Citation}

Alvarez, Cimmiaron, "The Polite Abuser: Using Politeness Theory To Examine Emotional Abuse" (2020). Theses and Dissertations. 1218.

https://ir.library.illinoisstate.edu/etd/1218

This Thesis is brought to you for free and open access by ISU ReD: Research and eData. It has been accepted for inclusion in Theses and Dissertations by an authorized administrator of ISU ReD: Research and eData. For more information, please contact ISUReD@ilstu.edu. 


\section{THE POLITE ABUSER: USING POLITENESS THEORY TO EXAMINE EMOTIONAL}

\section{ABUSE}

\section{CIMMIARON ALVAREZ}

86 Pages

Over the last few decades more and more cultural attention has been paid to intimate partner violence, especially emotional abuse. Follingstad, Rutledge, Berg, Hause, and Polek (1990) established that emotional abuse fell into six distinct categories; however, little attention had been paid to how abusers can utilize polite communication to hurt their partner. Equally, Brown and Levinson's politeness theory (1987) had never been applied to problematic communication until Austin's (1990) face attack acts model. This study aimed to understand how polite communication can be used as a form of emotional abuse. In-depth, semi structured interviews were conducted with 20 participants who self-identified as having been in a former romantic relationship with a partner who hurt their feelings, made them feel bad about themselves, or manipulated them. The utterances were categorized according to Brown and Levinson's (1987) politeness theory and Austin's (1990) face attack acts model of politeness. The utterances used by both abusers and their victims were then analyzed using thematic analysis. Abusers used all six of Austin's face attack act strategies, and victims responded using three of Brown and Levinson's four politeness strategies. Each strategy resulted in themes that abusers would utilize to hurt their partner. Implications of the study, limitations, and future research are then discussed. 
KEYWORDS: politeness theory, emotional abuse, face attack acts model, intimate partner violence, romantic relationships, communication 
THE POLITE ABUSER: USING POLITENESS THEORY TO EXAMINE EMOTIONAL ABUSE

CIMMIARON ALVAREZ

A Thesis Submitted in Partial Fulfillment of the Requirements for the Degree of

MASTER OF SCIENCE

School of Communication

ILLINOIS STATE UNIVERSITY 
(C) 2020 Cimmiaron Alvarez 
THE POLITE ABUSER: USING POLITENESS THEORY TO EXAMINE EMOTIONAL ABUSE

CIMMIARON ALVAREZ

COMMITTEE MEMBERS:

Aimee E. Miller-Ott, Chair

Lindsey Thomas

John R. Baldwin 


\section{ACKNOWLEDGMENTS}

First of all, thank you to my grandmother-without you, none of this would be possible. You answered all of my calls and listened to me think out loud for the last nine months. I appreciate you more than you know! Grandpa, you have always been my biggest cheerleader. Thank you for believing in me even when I didn't believe in myself. Cheyeanne and Camdon, thanks for being the best siblings a girl could ask for. Y'all have always been there to remind me that there is a world outside of academics when I needed it most. Dr. Miller-Ott, I could not have lucked out on a better advisor than you. Thank you for literally everything throughout this process. You have read and reread each and every version of this thesis. Without you, this would not be the project that it became. Dr. Thomas, thank you for being my Guru. Your emotional and academic support helped me not only get through this project but this program. Thank you for being you. Dr. Baldwin, thank you for teaching me the methods I identify with most. You literally taught me how to conduct this research. Dr. Miller-Ott, Dr. Thomas, and Dr. Baldwin, thank you all for agreeing to be on my committee. I know that y'all are on several committees and have spent this year reading, editing, and then rereading several students' drafts. I greatly appreciate the time that y'all spent working on my project as well.

C.A. 


\section{CONTENTS}

Page

ACKNOWLEDGMENTS

CHAPTER I: INTRODUCTION 1

CHAPTER II: REVIEW OF LITERATURE

Abusive Relationships $\quad 4$

$\begin{array}{ll}\text { Physical Abuse } & 7\end{array}$

$\begin{array}{ll}\text { Emotional Abuse } & 7\end{array}$

$\begin{array}{ll}\text { Politeness Theory } & 14\end{array}$

$\begin{array}{ll}\text { Face Theory } & 14\end{array}$

$\begin{array}{ll}\text { Politeness } & 15\end{array}$

$\begin{array}{ll}\text { The Dark Side of Politeness } & 20\end{array}$

$\begin{array}{ll}\text { Research Questions } & 28\end{array}$

$\begin{array}{ll}\text { Conclusion } & 29\end{array}$

$\begin{array}{ll}\text { CHAPTER III: METHODS } & 30\end{array}$

$\begin{array}{ll}\text { Participants } & 30\end{array}$

$\begin{array}{ll}\text { Procedures } & 31\end{array}$

$\begin{array}{ll}\text { Data Analysis } & 32\end{array}$

$\begin{array}{ll}\text { Conclusion } & 33\end{array}$

CHAPTER IV: RESULTS

Face Attack Acts Using Politeness 35

Bald-On-Record 35

On-Record with Inappropriate Redress $\quad 40$ 
Off Record 45

$\begin{array}{ll}\text { Politeness Strategies } & 46\end{array}$

Off Record

On-Record with Redress towards Positive Face $\quad 50$

Bald-On-Record

$\begin{array}{ll}\text { Conclusion } & 54\end{array}$

CHAPTER V: DISCUSSION

Summary of Findings $\quad 55$

Face Attack Acts of Politeness

$\begin{array}{lr}\text { Politeness Theory } & 59\end{array}$

$\begin{array}{ll}\text { Is Politeness Helpful? } & 60\end{array}$

$\begin{array}{ll}\text { Theoretical Implications } & 60\end{array}$

Applying Politeness to Dark-Sided Communication 61

$\begin{array}{ll}\text { Hybrid Messages } & 62\end{array}$

Non-Response as an Off-Record Tactic $\quad 63$

$\begin{array}{ll}\text { Practical Implications } & 64\end{array}$

$\begin{array}{ll}\text { Limitations } & 67\end{array}$

$\begin{array}{ll}\text { Future Research } & 68\end{array}$

$\begin{array}{ll}\text { Conclusion } & 70\end{array}$

$\begin{array}{ll}\text { REFERENCES } & 71\end{array}$

APPENDIX A: RESEARCH BOARD RECRUITMENT 79

APPENDIX B: EMAIL RECRUITMENT $\quad 80$

APPENDIX C: FACEBOOK RECRUITMENT 81 
APPENDIX D: INFORMED CONSENT

APPENDIX E: INTERVIEW PROTOCOL 


\section{CHAPTER I: INTRODUCTION}

In 2019, several women came out about their emotionally abusive relationships with the musician Ryan Adams (Coscarelli \& Ryzik, 2019). Adams' ex-wife, Mandy Moore, describes Adams as taking control of her music career, yet he never allowed her to record her music. When Adams did book studio time for Moore to record, he would give it away to other female artists, behavior that Moore considered psychologically abusive (Coscarelli \& Ryzik, 2019). In fact, Adams even told Moore that she was not a real musician, since she does not play an instrument (Coscarelli \& Ryzik, 2019). Moore was not his only victim. Twenty-year-old Phoebe Bridgers states that Adams was obsessive and emotionally abusive in their relationship as well (Coscarelli \& Ryzik, 2019). A few weeks into their relationship, Adams started bombarding Bridgers with texts asking her to prove her whereabouts and threatening suicide if she did not come to him immediately (Coscarelli \& Ryzik, 2019).

All of the women who accused Adams of inappropriate behavior described a pattern to his behavior (Grady, 2019). Adams' pattern started by approaching aspiring young musicians at the beginning of their careers praising their talent and asking them to work with him (Grady, 2019). If the young musician was receptive, Adams then introduced sex into the conversation with the women. When women rejected Adams, he would withdraw professional attention, as he did with Bridgers (Coscarelli \& Ryzik, 2019). Once Bridgers broke off her relationship with Adams, he withdrew his offer for her to open for him during his tour (Coscarelli \& Ryzik, 2019).

The National Coalition Against Domestic Violence (n.d.) reports that ten million individuals experience physical intimate violence each year in the United States. Of all violent crime, $15 \%$ is domestic abuse. Domestic violence affects one in four women and one in seven men (Black et al., 2011). As a result of domestic violence, these individuals can experience 
injury, mental illness, and health consequences (Black et al., 2011). While domestic violence is often discussed as physical violence, it also includes emotional abuse, as in the Ryan Adams example. In fact, nearly half of all individuals have experienced emotional abuse within their romantic relationships at least once ("The National Domestic Violence Hotline," n.d.). Just as physical abuse is used to control another individual, emotional abusers use emotions as a weapon to control their partners (Mathews, 2016). However, while physical abuse is consciously used by the abuser, when it comes to psychological abuse, the abuser may not realize that their behavior is abusive (Mathews, 2016).

This study investigates the less explicit forms of domestic violence by examining the way partners manipulate politeness to continue emotional abuse. Using politeness theory as a lens for studying abuse allowed the researcher to examine verbal messages used in psychological abuse. While politeness has been studied in a variety of contexts, very little research has been done on how it can be manipulated for dark-sided communication. Austin (1990) established how politeness can be manipulated, but that framework has never been applied to a relational context. In this thesis, I examine the previous literature on domestic violence and politeness theory before thematically analyzing transcripts of semi-structured interviews to determine how both victims and abusers linguistically utilize politeness strategies when communicating in their relationships. 


\section{CHAPTER II: REVIEW OF LITERATURE}

The United States Department of Justice (n.d.) defines domestic violence as "violence committed by a current or former spouse or intimate partner of the victim, by a person with whom the victim shares a child in common, by a person who is cohabitating with or has cohabitated with the victim as a spouse or intimate partner, by a person similarly situated to a spouse of the victim under the domestic or family violence laws of the jurisdiction receiving grant monies, or by any other person against an adult or youth victim who is protected from that person's acts under the domestic or family violence laws of the jurisdiction" (para. 2).

The National Coalition Against Domestic Violence (n.d.) establishes violence as "the willful intimidation, physical assault, battery, sexual assault, and/or other abusive behavior as part of a systematic pattern of power and control," including "physical violence, sexual violence, threats, and emotional/psychological abuse" (para. 1). Intimate partner violence is often used as a synonym for domestic violence.

While abusive relationships have been studied in a multitude of contexts, the linguistics of abuse, that is the words than an abuser uses to control or abuse their partner, have not been studied. This review of literature gives an overview of abusive relationships before focusing on emotional abuse and the specific types of abuse found within these relationships. An overview of face theory precedes an examination of politeness theory. Once I have provided the theoretical basis, specifically how politeness can be manipulated in relationships, I will lead into the research questions of this study. The purpose of this study is to examine how abusive partners manipulate politeness to continue emotional abuse. 


\begin{abstract}
Abusive Relationships
Common depictions of domestic violence paint a picture of a male perpetrator subjecting a woman to victimization, typically using physical abuse (Allen-Collinson, 2011). However, when it comes to violence toward their intimate partners, men and women use the same amount (Hamby, 2016). Anyone can be a perpetrator or victim of domestic violence and abuse, and more men are reporting their abuse than before ("Police are Recording," 2018). However, some factors may influence one's chances of experiencing physical aggression or are results of abuse. For instance, Ebbeler, Grau, and Banse (2017) conducted a multilevel analysis of physical aggression among married couples in 34 countries. They found that couples who were younger or of lower socioeconomic status and had less equality in decision-making were more likely to engage in physical aggression. In addition, relationships in which partners are both part of the decisionmaking process had lower amounts of relational aggression. Murray-Close, Ostrov, Nelson, Crick, and Coccaro (2010) defined relational aggression in romantic relationships as expressions of anger, hostility, impulsivity, history of abuse, hostile attribution biases, and emotional sensitivity to relational provocations.

Walker (1977) describes how, rather than continuous abuse, domestic violence tends to follow a three-phase cycle which can vary in both time and intensity. The cycle begins with tension-building, then comes to a climax with an acute battering incident, and then finishes with a calm and loving interval. The cycle can become apparent to the victim throughout their relationship with the abuser, sometimes allowing the victim even to predict behavior (AllenCollinson, 2011). In fact, situational context can influence the timing of the cycle and the length of each of the phases (Walker, 1977). The third phase, loving, is what keeps the cycle going. During this time, all of the relational rewards, or what the victim wants out of the relationship,
\end{abstract}


are present. Since the third phase occurs after the battering incident, it is difficult for victims to leave because they believe that their abusers loving nature can last. In addition, victims, especially female victims, choose to stay with their abusive partners because of the length of the relationship and the fact that they have a child with the abusive partner (Byers, Shue, \& Marshall, 2004).

Individuals who are in abusive relationships communicate with their partners differently than those who are not in an abusive relationship (Rudd \& Burant, 1995). People seek out social connections with others, and when these connections result in positive social interactions, these social connections increase the perception of one's own and others' humanity (Bastian, 2019). However, when an abuser victimizes their partner, they dehumanize both themselves and the victim (Bastian, 2019). Dehumanization is when an individual treats or perceives another as less than human (Pizzirani and Karantzas, 2019). Pizzirani and Karantzas (2019) graphed dehumanization over a six-week period and found that the perpetration of dehumanization is associated with increases in both physical and emotional abuse. Dehumanization increases the victim's dependence on the perpetrator despite the low satisfaction in the relationship because they do not believe themselves as worthy of the satisfaction (Bastian, 2019). Abusive relationships continue when a perpetrator dehumanizes the victim but not themselves, when the victim self-dehumanizes but fails to dehumanize the abuser, and when third party observers dehumanize the victim (Bastian, 2019). Pence and Paymar (1993) created a power control wheel and established dehumanization, similar to Bastian (2019), as male privilege, or how men keep control of the relationship. An abuser uses male privilege when they respond to authority challenges with controlling and abusive behavior as a way to maintain control (Pence \& Paymar, 1993). As a result of such dehumanization, both the victim and perpetrator justify the abusive 
behavior, the victim sees themselves as unworthy of other relationships or financially dependent on the abuser, and third-party observers reduce the social value of victims (Bastian, 2019; Pence \& Paymar, 1993).

An abuser dehumanizes their victims in order to downplay their abusive actions (Bastian, 2019). In contrast, victims dehumanize their abusers as a way to minimize the impact of the abuse (Bastian, 2019). Victims self-dehumanize as well, often as a way to make their abuse feel as if it is deserved (Bastian, 2019). As a result of this self-dehumanization, victims are less motivated to leave or to retaliate against their abuser, protecting the relationship (Bastian, 2019). Perpetrators also engage in self-dehumanization after engaging in abusive behavior (Bastian, 2019). After an abusive act where a perpetrator self-dehumanizes, they are more likely to engage in a prosocial behavior, such as being extra compassionate to their partner, as a way to reclaim their humanity (Bastian, 2019). A perpetrator's self-dehumanization and subsequent prosocial behavior may explain the third (loving) stage in the violence cycle. Abusers self-dehumanize, love, and comfort their partners and once they feel as if they have regained their humanity, they go back to the abusive behavior.

Abuse in a relationship can take many different forms; the two categories typically established within domestic violence are physical abuse and emotional abuse (Fletcher, 2018). Physical and emotional abuse include experiences of humiliation, emotional manipulation, and physical assault within a romantic relationship (Fletcher, 2018). Fletcher (2018) argues in an autoethnography that "abuse is chaotic and cannot be fully articulated by, or neatly parceled into, preexisting constructs such as psychological partner aggression, romantic attachment, and negative relational maintenance" (p. 47). The types of abuse often occur in tandem with each other, making it difficult to separate one from the other. 


\section{Physical Abuse}

Physical forms of abuse affect more than one in three women and more than one in four men in the United States (Black et al., 2011). Of couples who report physical violence and aggression in their relationships, almost 50 percent engage in symmetrical physical aggression (Whitaker, Hailevesus, Swahn, \& Saltzman, 2007), in which both partners are violent and aggressive toward each other. In relationships where only one partner was violent, the perpetrator was a woman seventy percent of the time (Whitaker et al., 2007). A predominant view of domestic violence is that when women do engage in physical aggression, they do so as a result of self-defense (Leisring, 2013). However, female participants in Leisring's (2013) study rarely indicated self-defense was the reason for their violence toward their partner. Women engage in intimate partner violence because of anger, retaliation, jealousy, stress, as well as, to get a partner's attention. Yet, violent men inflicted more injuries toward their victimized partner than women (Whitaker et al., 2007). Intimate partner violence can result in posttraumatic stress disorder, depression, physical injury, reproductive health problems, irritable bowel syndrome, and chronic pain (Whitaker et al., 2007). Intimate partner violence disproportionately affects poor uneducated women of a minority status (Aizer, 2011).

While physical abuse is a major issue, this thesis will focus on emotional abuse. Abuse is communicative, but emotional abuse is more verbally communicative. Since physical abuse leaves visible wounds, more time is dedicated to reducing its harm; however, emotional abuse can harm victims as well and is the focus of this thesis.

\section{Emotional Abuse}

Along with physical violence, domestic violence victims can be subjected to sustained emotional abuse (Allen-Collinson, 2011). Emotional abuse is when a perpetrator attempts to 
make their partner feel bad about themselves (Pence \& Paymar, 1993). In fact, emotional abuse is closely linked to verbal abuse (Brown, 2018). Verbal abuse includes toxic language and aggressive verbal attacks that can impact the victim not only mentally (Fletcher, 2018). In their study, Abowitz, Knox, and Zusman (2010) found that undergraduates who were most likely to report emotional abuse were women, those who ranked as a senior, those in a friends-withbenefits relationship, those who sought a partner online, romantic students who believed in love at first sight, those who had previously experienced intimate partner violence, or those who had experienced previous sexual victimization. The strongest predictor of a male perpetrating emotional abuse in heterosexual relationships is the male partners' stress levels (Gormley \& Lopez, 2018). Gormley and Lopez (2010) found that the more stressed the male partner was, the more they perpetrated psychological abuse, but for women, psychological abuse perpetration was consistent despite stress levels.

Victims who are facing emotional abuse can have difficulty separating themselves from their abuser (Fletcher, 2018). Emotional abuse can make the victim feel as if they have no control over their lives. Fletcher (2018) states,

It felt as though all of my decisions were dictated by this other person. What I wore, whom I spoke to, what I did with my time and money-all were decided or heavily influenced by him. I was scolded, punished, and dominated on a regular basis. It was as if I had regressed into the state of being a child, incapable of functioning separately from him. (p. 52)

Emotional abuse can cause the victim to engage in dangerous self-scrutinizing behavior. Even after a victim leaves an abusive relationship, emotional abuse can leave lasting scars in the form of 'quirky' behaviors, such as leaving a cell phone face down on a table, that were once a part of 
survival (Fletcher, 2018) and has a long-term impact on emotional health (Lammers, Ritchie, \& Robertson, 2005).

There are six types of emotional abuse often used as a form of coercive power (Follingstad, Rutledge, Berg, Hause, \& Polek, 1990). The first type of emotional abuse is a verbal attack which can manifest as ridicule, verbal harassment, name-calling, or public humiliation (Follingstad et al., 1990). Batterers use mocking and insults to make the victim feel as if they are deserving of punishment (Pence \& Paymar, 1993). Verbal abuse is used as a way to control the victim, making them believe they are not worthwhile (Follingstad et al., 1990; Pence \& Paymar, 1993). As a result of verbal abuse, victims remain under the power of the abuser.

Isolation, whether social or financial, is the second form of emotional abuse (Follingstad et al., 1990). The function of isolation is to ensure the victim does not have social support systems to help them leave or the financial power to do so. As a result of isolation, victims lose their independence, becoming dependent on their abusive partner. Isolation also diminishes the victim's ability to effectively deal with the abuse both financially and socially. As a result, Zavala and Spohn (2010) found that women with more resources, either educational or financial, were less vulnerable to psychological abuse.

The third type of emotional abuse is jealousy and possessiveness (Follingstad et al., 1990). Abusers become jealous of everyone in the victim's life from family to friends, even pets. Jealousy, which is not inherently abusive, becomes abusive when the abuser interrogates the victim about strangers or other potential partners with whom they come into contact, often accusing the victim of infidelity. During periods of jealousy, abusers use intimidation, through either words or looks, to impact the victim's behavior (Brown, 2018). As early as during adolescence, young abusers can use technology to check their partner's messages and online 
accounts (Stonard, Bowen, Walker, \& Price, 2017). Checking message histories allows partners to determine with whom their partners have been talking as a way to ensure their partner is not engaging in infidelity. A partner's expression of their jealousy can control the victim's behavior from what clothes they wear to their conversational partners (Follingstad et al., 1990).

Verbal threats are another form of emotional abuse (Follingstad et al., 1990). Verbal threats include threats of abuse, harm, or torture. Some victims have even experienced verbal threats that included graphic descriptions of how their abuser planned to torture them. While threats are directed toward the victim, they can also be directed toward the victim's family members, children, or even friends. While they sound similar, emotional blackmail, the fifth type of emotional abuse, is distinct from verbal threats (Follingstad et al., 1990). Emotional blackmail includes threats the abuser makes about divorcing or abandoning the victim or having an affair if the victim fails to comply. Within emotional blackmail is the denial of the victim's abuse or blaming the victim for abuse (Pence \& Paymar, 1993). Rather than just making threats, the final type of emotional abuse is the destruction of the victim's personal property (Follingstad et al., 1990).

Abusers will use their love of the victim as a way to excuse their abusive behavior (Brown, 2018). Consequently, Karakurt and Silver (2013) report emotional abuse varies with the victims' age and gender. Younger men experience emotional abuse more often than younger women. Emotional abuse declines with age for both men and women; however, older women experience less emotional abuse than older men. In contrast, younger women experience more isolation and higher rates of property damage than men. As women age, their experience of property damage increases. When status incompatibilities within relationships favor women, there is an increased likelihood of emotional abuse (Kaukinen, 2004). 
Female victims of male emotional abusers often perceive their partners to expect to be the authority figure (Lammers et al., 2005). As a result, male partners conformed to the standard male gender role by establishing the rules and standards of the relationship. Women reported in interviews to Lammers et al. (2005), that their male partners expected special privileges, had to be seen as right, and behaved in a self-righteous manner. In their study, Zavala and GuadalupeDiaz (2018) found that participants who demonstrated more self-control were likely to also report being a victim of emotional abuse. High self-control may be viewed as a threat to the abuser's ability to control their victim, leading abusers to establish power dynamics through emotional abuse. While victims viewed their partner's behavior as conforming to masculine control, abusers did not always make these assumptions overt (Lammers et al., 2005).

Gaslighting. A type of emotional abuse is gaslighting, or the attempt to undermine a victim by denying the harms that were done to them by their abuser (Stark, 2019). Like the patterns of abuse, gaslighting has its own pattern that begins with the abuser verbally attacking the victim (Dorpat, 1994). The second phase in the gaslighting pattern is the victim's response to the verbal abuse. Finally, the abuser uses gaslighting to attack the victim's judgments. Gaslighters get their victims to doubt their testimony by using two tactics, sidestepping and displacing, to challenge the credibility of the statement (Stark, 2019). Sidestepping involves the abuser dodging evidence that supports the victim's testimony. For example, an abuser who is late to dinner may use sidestepping by justifying their lateness, refusing to give their victim a chance to be frustrated with the tardiness. Displacing, in contrast to sidestepping, discounts the victim's testimony by attributing the testimony to defects in their cognition or character (Stark, 2019).

While gaslighting sounds like one partner simply dismissing the other, it goes much deeper than that. Dismissing someone means that one partner fails to take the other seriously. 
Gaslighting, on the other hand, is aimed at the abuser getting the victim to not take themselves seriously (Abramson, 2014). It is as if the abuser convinces their victim that they are losing their grip on reality (Wozolek, 2018). One way that a gaslighter can do this is by labeling the victim's reactions to abuse as a negative stereotypical attitude (Gass \& Nichols, 1988). For example, gaslighters will repeat statements such as, "You are making things up," "It is all in your head," or "You have a bad memory," in order to manipulate their victims.

Manipulation. Another type of emotional abuse an abuser might use is to use communication to manipulate their victims (Allen-Collinson, 2011). One way an abuser can manipulate their partner is by controlling the partner's agency through the control, destruction, or concealment of government-issued forms of identification, such as birth certificates, social security cards, and credit cards. Without these documents that confirm identity, it is difficult for the victim to get a job or to travel. Abusers can also utilize digital technology to manipulate their partner's behavior and establish control (Dragiewicz et al., 2018).

Abusers, especially female abusers who use manipulation to control their partners, have high levels of Machiavellianism (Brewer \& Abell, 2017). Machiavellianism is a personality trait in which individuals are more willing than the average person to manipulate and exploit others. Women high in Machiavellianism use manipulation to increase their partner's dependency, lower their partner's self-esteem, increase their partner's insecurity about the relationship, and produce submission (Brewer \& Abell, 2017). Allen-Collinson (2011) interviewed a man who was abused by his wife for nearly twenty years. As the wife's abuse developed, she confiscated the man's keys and refused to return them. Reducing the husband to pre-adult status, the wife prevented him from leaving or entering the home without her control or knowledge. 
One way that abusers manipulate their victims' behavior is through the use of digital media (Dragiewicz et al., 2018). Dragiwicz et al. (2018) reported technology-facilitated coercive control is the term used to describe the behavior of using technology to perpetuate patterns of abuse against an intimate partner. The various modes of digital media platforms, especially social media, allow abusers to keep more tabs on their victims, amplifying and expanding the abuse, as well as providing an outlet for public humiliation. Social media can be used by abusers to intimidate, micromanage, dominate, and isolate victims. When victims try to leave an abusive relationship, social media may be used by their abusers to track them down or to continue dominance through humiliation such as by posting revenge porn. Beyond coercive control, technology may be used to manipulate victims in the form of romance fraud (Cross, Dragiewicz, \& Richards, 2018). Through romance fraud, abusers convince victims that they are in a romantic relationship with the victim so that the victim will send the abuser money, allowing technology to be used for economic abuse.

Lutgen-Sandvik (2003) established emotional abuse as "repetitive, targeted, and destructive form of communication" (p. 472). Brown (2018) explains that emotional abuse is a way that partners can control their significant other, and this can include controlling their social lives. The way that an abusive partner establishes this control is through communication. Emotional abuse is communicated through verbal communication, such as the vocalization of abusive statements, and non-verbal communication, such as the tone of voice or body language that an abuser communicates. Abuse is an inherently communicative act. Abusive partners' use of emotional abuse establishes themselves as dominant (Dragiwicz et al., 2018) communicating to their victims that they are less than their abuser. 
Emotional abuse is prevalent and can be perpetrated by anyone. Emotional abuse must be examined as communication, including how partners might manipulate communication to continue emotional abuse. In order to better understand how partners may manipulate communication, a theoretical perspective is necessary. Politeness theory is used to establish a foundation for the ways that abusers may enact and communicate emotional abuse.

\section{Politeness Theory}

Brown and Levinson (1987) developed politeness theory based on Goffman's (1959) face theory. Since politeness stems from face, face is explained first in order to understand politeness. Face and politeness are the theories that I will use to examine how partners manipulate politeness to continue emotional abuse. In the following section, I will give an overview of each theory before examining the dark side of politeness theory.

\section{Face Theory}

Through face theory, Goffman (1959) established that, while communicating, individuals put on a performance or face. The face that one establishes is based on the context of the communication as well as the way they would like to present themselves to their communication partners. Individuals choose a face that is both socially and morally acceptable to others using verbal symbols or their substitutes to convey acceptability, referred to as an individual's front performance. Goffman argued that "society is organized on the principle that any individual who possesses certain social characteristics has a moral right to expect that others will value and treat [them] in an appropriate way" (p. 13). In order to ensure that their communication partners will uphold their face performances, communicators will uphold their partners' face in a reciprocal nature. Upholding another's performance, or helping them save face, is a societal norm, one that has been established through the ritual repetition of the behavior (Moore, 2017). 
While face theory is interpretive, Moore (2017) established a critical perspective on the theory. Face negotiations are "constrained contexts where individuals are evaluated and sometimes punished," creating a foundation of power (p. 263). The performance of face itself establishes that some forms of identity are superior to others. Performances of face that are deemed unacceptable are subject to social disciplinary action. As a result, "negotiations of face reinscribe relations of power by regimenting identity categories" (p. 263). For example, heteronormative behavior is viewed as socially acceptable. Therefore, when individuals violate gender norms, such as a woman being physically abusive to their male partner, they will be treated in a way that establishes that they need to confine themselves to the heteronormative norms that are socially acceptable. One way that individuals reinscribe socially desired performances is through the use of politeness.

\section{Politeness}

All individuals understand that they, as well as others, have face performances and that they want to work to protect both parties' faces (Brown \& Levinson, 1987). One way to protect face is through politeness. "Politeness is the communicative mechanism by which the wants of one individual are reconciled with the wants of another" (Dillard, Wilson, Tusing, \& Kinney, 1999, p. 289). In relationships, individuals seek to change the behavior of their relational partners if they need to negotiate the relationship (Dillard et al., 1999). In order to accomplish the goal of changed behavior, a communicator uses requests, offers, criticisms, complaints, and suggestions, all of which inherently threaten face (Brown \& Levinson, 1987). However, in order to accomplish certain goals, individuals need the cooperation of others. Individuals uphold face relationally through the use of politeness because their goals depend on it. For example, if one partner fails to consider the other when it comes to making certain decisions, rather than 
attacking their partner, the individual may say, "Next time we go out to dinner, could we make the decision together?" The partner trying to change behavior may add an extra layer of politeness by giving a reason (or "account") to justify the behavior change, such as "I have a gluten allergy, and there are places that do not provide gluten-free options." Politeness behavior may be an indicator of relational health. For example, Yokotani (2015) found the more a couple fails to properly use politeness, the more likely they are to engage in domestic violence. In fact, Brown and Levinson introduce two main types of face, positive and negative, in which politeness is directed.

Positive face. Positive face is the socially desirable self-image that an individual wants to portray to others (Brown \& Levinson, 1987). Individuals desire to be approved of by society and be recognized as having a value within the society (Austin, 1990), so they portray their positive face to ensure that they are (Brown \& Levinson, 1987). A positive face that is approved of by society ensures that the individual can accomplish their goals because they can convince others that their wants are similar.

When a speaker threatens an addressee's positive face, they may convey that they are unconcerned with the other's feelings or wants (Brown \& Levinson, 1987). Brown and Levinson explain speakers show the addressee that they negatively view certain aspects of the addressee's positive face when they engage in acts such as criticism, contempt, ridicule, complaints, reprimands, accusations, insults, contradictions, disagreements, challenges, or expressions of disapproval. Such acts establish that the speaker does not care about the addressee's positive face as a whole. A speaker can threaten their own positive face by apologizing, accepting compliments, losing control over their body, humiliating themselves, shuffling, cowering, contradicting themselves, confessing, or by having emotional leakage. 
Negative face. Negative face is an individual's desire to be free from imposition (Brown \& Levinson, 1987). An individual wants to have the ability to make their own decisions and accomplish their own goals. Negative face ensures that an individual can maintain their selfesteem by having freedom of action within general societal boundaries (Austin, 1990). When negative face is threatened, the individual is no longer free from imposition (Brown \& Levinson, 1987). Instead, the addressee is now obligated to perform an action, often as a way to uphold their positive face.

A speaker threatens the addressee's negative face when they ask the addressee to perform a future act, violating the addressee's freedom (Brown \& Levinson, 1987). Orders, requests, suggestions, advice, reminders, threats, warnings, or dares all threaten the addressee's negative face. Other acts that threaten an addressee's negative face come in the form of promises and offers because the speaker is predicting a future action that the addressee must rely on. Even compliments, expressions of envy, admiration, or negative motions toward the addressee can threaten their negative face by requiring the addressee to protect the object of the speaker's desire. A speaker can threaten their own negative face when they express thanks, accept an addressee's thanks or apology, make excuses, accept offers, respond to an addressee's faux pas, or make unwilling promises and offers. Johnson, Roloff, and Riffee (2004) examined the relationship between refusals of requests and face threats. They found that when an addressee refuses the request of a speaker, the speaker experiences a greater threat to their negative face than the addressee does.

Face threatening acts. When engaging in a face-threatening act (FTA), the speaker may use polite language to reduce the threat (Brown \& Levinson, 1987). Politeness is often discussed linguistically with the politeness of an utterance depending on how it is phrased by the speaker. 
For example, phrasing a request as a question is considered more polite than ordering the addressee to perform a task because it leaves the decision to engage in such a task up to the addressee (Lakoff, 1973). In fact, the more words a speaker uses during the face-threatening utterance, the more the utterance sounds like a suggestion and the more polite it is considered. Reminding the addressee of something that makes them uncomfortable, such as strong statements, is impolite and therefore, an FTA (Lakoff, 1973). As a result, Lakoff (1973) established that politeness requires that speakers often avoid strong statements. However, avoiding strong statements is gendered. Women are socialized to believe that part of their face is to avoid strong statements that may make the addressee uncomfortable. Thus, women often engage in politeness strategies more than men and are considered more polite. For both genders, FTAs impede on both positive and negative face (Brown \& Levinson, 1987).

Politeness strategies. Brown and Levinson (1987) established that the seriousness of an FTA depends on three sociological variables: the social distance between the speaker and the addressee, or the symmetric relation; the relative power between the speaker and the addressee, or the asymmetric relation; and the ranking of imposition. Both the speaker and the addressee must have mutual knowledge of these three factors and their values in order to address the seriousness of a face threat. Rather than the seriousness of the threat being based on the absolute value of the factors, it is based on the perceived value of them.

In order to protect the face of the addressee as well as themselves, speakers try to avoid FTAs. However, Brown and Levinson (1987) report that in order to accomplish certain goals, individuals must threaten face. When face-threatening acts are necessary, politeness strategies minimize the face threat. Which strategy the speaker uses depends on the content of the facethreatening act, speaker's desire for efficiency, degree to which speaker wants to maintain the 
addressee's face, and the seriousness of the threat. Speakers should choose a politeness strategy appropriate for the threatening act. However, politeness involves effort, and the speaker may choose an inappropriate strategy because it is more convenient.

Brown and Levinson (1987) introduce an off-record approach as one politeness strategy a speaker can use to safe face. When a speaker uses an off-record approach, they do not commit themselves to a particular intent. Off-record utterances indirectly state what the speaker wishes to communicate so that the meaning is negotiable. Metaphors, irony, rhetorical questions, understatements, tautologies, and hints are all forms of an off-record strategy of politeness. For instance, an abused partner might ask a rhetorical question like, "Wouldn't it be nice for you to come home and not be upset with me about something?" Meanwhile, victims of emotional abuse may respond using an off-record approach such as, "I'm tired and going to bed," rather than communicating their anger to their partner.

When a speaker uses an on-record strategy, they make their communicative intention clear to the speaker (Brown \& Levinson, 1987). On-record strategies reduce ambiguity, ensuring that the addressee knows the purpose of the speaker's face-threatening act. The clearest and most concise on-record strategy is one that is done without redress, called bald-on-record. This strategy is only used when the speaker does not fear retribution. For instance, an abuser might say, "You are a disgusting person." Circumstances that may result in the use of an on-record strategy without redress are when there is a need for urgency, when the danger to face is very small, or when the speaker has more power than the addressee. Often this strategy is the least polite. Bald-on-record strategies are probably the least likely to be used by a victim toward their abusive partner. If this strategy is used, it is most likely used when the abused partner declares 
that they are leaving their abuser. However, abusers might use a lot of bald-on-record strategies stating something along the lines of, "Don't eat that cookie. You're going to get fat."

A speaker can go on-record while still using redressive action by giving face to the addressee to counteract the face damage of the utterance (Brown \& Levinson, 1987). Redressive action modifies or adds to the utterance to clearly indicate that the speaker does not intend or desire to threaten the face of the addressee. There are two types of redressive action: positive politeness and negative politeness, each oriented toward a type of face. Positive politeness indicates that the speaker wants the same as what the addressee wants, minimizing positive face threat. An abused partner may tell their partner that "it is time we seek counseling because we both want this relationship to work." An abuser, meanwhile, might use positive politeness stating, "We want to present a united front to the children, so let's agree on our decisions" (with it understood that the partner should agree with the abuser's decisions). Negative politeness is avoidance-based, assuring the addressee that the speaker's face threat will not, or will only minimally, impede on the addressee's freedom. Victims may ask their abusers "I understand you're angry, but can we wait until we are down the hall in our room away from the children?" Abusers may state, "It's not hard for you to send me a text when you're out with your friends. You know I care about you, and it will only take two seconds."

\section{The Dark Side of Politeness}

While politeness is often seen as a way to build and maintain relationships, it can also be used by a speaker to manipulate or control their partner. The dark side of politeness is how politeness strategies are manipulated in order to attack face rather than maintain it.

Face attack acts. Austin (1990) argued that the same politeness strategies that are used to save face can be manipulated and used for face attacks. What distinguishes a face-saving 
strategy from a face attack is the context in which the utterance is produced, including the addressee's assumptions, the physical environment, and visual clues. While politeness theory relies on cooperation (Brown \& Levinson, 1987), the model of face attack is one where the speaker wishes to communicate but not necessarily cooperate. Instead, the dark side of politeness is characterized by what Austin (1990) called face attack acts.

Face attack acts are those "communicative acts which are injurious to the hearer's positive or negative face and are introduced in a situation which could have been avoided; but where their inclusion is perceived by the hearer to be intentional" (Austin, 1990, p. 279). A key aspect of face attack acts is that they are perceived by the addressee as intentional; however, they may not be. As a result, certain assumptions from Brown and Levinson's (1987) theory are violated, such as the assumption that the speaker wants to maintain the addressee's face, that the addressee poses a threat to the speaker's face, and that the speaker cares about potential retaliation from the addressee (Austin, 1990). In Brown and Levinson's (1987) theory, the more an act threatens the addressee or speaker's face, the more the speaker will consider using politeness strategies such as redressive actions or going off record. Conversely, this is not a consideration in Austin's (1990) face attack model of politeness.

Previous iterations of politeness have focused on linguistic aspects of politeness (Lakoff, 1973; Brown \& Levinson, 1987). Austin (1990) discusses the dark side of politeness as including non-verbal behavior, both tonal and kinetic. Redressive action during face attack acts do not have to be verbal but can include warning tones or leers. Like politeness strategies, face attack acts can be bald-on-record, on-record, or off-record.

Manipulation of politeness. A key consideration for whether or not an individual can engage in a face attack is the power that they have within the interaction (Austin, 1990). The 
more power the speaker has within the interaction, the more they can be humiliating and coercive without fearing retribution by the addressee. When the speaker has more power than the addressee, the addressee cannot be expected to defend their own face. If the addressee has significantly less power than the speaker, face defense could result in consequences that are more damaging than the face attack, such as the loss of physical safety. In abusive relationships, the abuser has physical, financial, or emotional power over the victim. As a result, an abuser may manipulate politeness as a way to maintain their power over their partner.

Another important consideration in whether one makes a face attack is the solidarity between the speaker and addressee (Austin, 1990). Solidarity is the degree of intimacy between the interactants of an utterance. "In some cases, solidarity is so great that the individuals concerned will tolerate face attack acts which would otherwise cause a lot of hurt, particularly among groups such as families and participants in intimate relationships" (Austin, 1990, p. 280). As a result, members might endure attacks from other members and not retaliate to hold the group together. Since abusive relationships include intimacy and therefore solidarity, victims may allow their abusive partner to cross the lines of politeness over and over again.

Power and solidarity interact with each other to create politeness boundaries (Austin, 1990). The more power a speaker has, the more ability they have to adjust the solidarity variable. As a result, the addressee who has less power is unsure where the level of solidarity is to properly interact within the context of the interaction. For example, during one interaction, the speaker with more power may show increased intimacy. During the next interaction, the addressee may show intimacy on the level of the first speaker during the previous interaction. However, the person with power can redefine the intimacy by showing less solidarity and 
establishing distance between themselves and the addressee (Austin, 1990). This redefinition could result in the cycle of abuse (Walker, 1977).

The final consideration for the ability to manipulate politeness is the ability to use a certain language, more specifically sexist language (Austin, 1990). Men can manipulate language as a means to keep women out of influential positions. Male speakers with power can define group membership so that women cannot join the membership of elites. As a result, men reinforce a woman's out-group status by using differential naming practices, in-group jargon, and jokes, all of which women are not privy to. While Austin established sexist language as manipulation, the fact that men are more likely to experience emotional abuse (Karakurt \& Silver, 2013) suggests that this may not be a factor in emotionally abusive relationships.

In combination, those who have access to these three factors (power, solidarity, and language) have the ability to utilize face attacks (Austin, 1990). Those who possess all three factors are able to manipulate politeness without fear of retaliation. Those who lack one or more of these factors are at a disadvantage, unable to manipulate politeness in the same way. Without these factors, addressees take face into consideration, ensuring that they maintain theirs and the speaker's face. As a result, they can be manipulated through the politeness strategies that are (or are not) used.

Types of face attack acts. Based on the power the speaker has, the solidarity between the addressee and the speaker, and the language the speaker plans on using, the speaker may choose different face attack strategies. Austin's (1990) face attack strategies are similar to Brown and Levinson's politeness strategies. Brown and Levinson's (1987) strategies focus on how best to save the face of both the speaker and the addressee. However, Austin's face attacks are the 
manipulation of politeness based on power, solidarity, and language as a way to accomplish the speaker's goals, usually without the consideration of the addressee's face.

Bald-on-record. Similar to Brown and Levinson's (1987) conceptualization of the baldon-record strategy, Austin (1990) describes that these types of face attacks pay minimal attention to the addressee's face wants. This type of face act goes on the record in making the face attack but fails to use any redressive actions in the process. The speaker understands the addressee has positive face needs but does not accommodate them. The result of a bald on-record face attack is an addressee that is insulted in the process. Abusive partners may explicitly call their partners "dumb," "inconsiderate," or "crazy."

Austin (1990) argues that there are more effective ways for the speaker to attack the addressee's face since this approach often leaves the speaker looking rude. As a result, bald onrecord strategies only appear when the risk to the speaker's face is minimal. Bald-on-record face attacks occur most often when there is a power imbalance between the speaker, who has more power, and the addressee, who has significantly less power, such as in abusive relationships. With an asymmetrical power grouping, there is less of a need to minimize face threats to the addressee.

Bald-on-record face attacks can target the addressee's positive or negative face (Austin, 1990). When the speaker is disrespectful or speaks about taboo topics, they are attacking the addressee's positive face. Bald on-record attacks to positive face include the speaker referencing the addressee's sexual characteristics, often in a derogatory way. Attacking their partner's positive face, an abuser may discuss sexually explicit acts to make their partner uncomfortable. Attacks to the addressee's negative face occur when the speaker fails to consider the addressee's negative face although they are aware that the negative face need exists. Speakers who use a bald 
on-record approach to attack an addressee's negative face are engaging in direct coercion. When attacking negative face, an abuser may demand that the victim perform certain acts, such as going to the abuser's work function while the victim has a friend's graduation to attend.

On-record with inappropriate redress. When engaging in on-record face attacks with inappropriate redress, the speaker uses strategies to save the speaker's face (Austin, 1990). Inappropriate redress is used when the speaker uses a verbal attack that is harsh and direct, or onrecord, but they try to include a small disclaimer, or redressive action, as a way to try to save their partner's face. While some action is taken to save the addressee's face, the interaction or the relationship between the speaker and addressee makes the redressive action inadequate (Austin, 1990). For example, an abusive partner might say "no offense, but" when criticizing their partner's decision. However, there may have been talk in the relationship to be open and honest, but saying "no offense, but" establishes that the abusive partner does not view the communication as open and honest as their partner did because the abuser felt the need to use a redressive action. On-record with inappropriate action is not only humiliating to the addressee but also can be coercive (Austin, 1990). Abusive partners might tell their partner "no offense, but your voice is annoying and always nagging me." In this case, the speaker is using on-record with inappropriate redress, the redress being "no offense." Inappropriate redress may be used by the speaker to save their own face but is often unsuccessful.

Like bald on-record face attacks, those that are on-record with inappropriate redress can be oriented toward the addressee's positive face (Austin, 1990). When a speaker inappropriately orients toward an addressee's positive face, they use a polite hedge or qualification to face attacks that do not need a redress, often coming off as condescending (Austin, 1990). An abusive partner may criticize what the victim is wearing by saying "You're sexy without showing so 
much skin. Why don't you wear the red top with a higher neckline?" Addressees interpret redressive action to positive face in one of three ways: 1) "the speaker has different ideas from the [addressee] about appropriate behavior" (Austin, 1990, p. 284), such as the no offense example above; 2) "the speaker thinks that the [addressee] is not capable of withstanding bald on-record utterances" (Austin, 1990, p. 284), such as an abusive partner saying "I know you don't like to hear this, but you didn't tell me where you were, again;" or 3) "the speaker is trying to redefine the relationship in a way which is harmful to the [addressee's] interests" (Austin, 1990, p. 284), such as, "Share your location with me so I can ensure that you are always safe." These interpretations can lead the addressee to lose self-esteem or self-image, causing them to modify their future behavior; therefore, face attacks with inappropriate redress can be coercive (Austin, 1990). Due to their coercive behavior, face attacks with inappropriate redress can also be a form of gaslighting. For example, an abused partner might say, "You are so controlling, you always want to know where I am.” The abusive partner might then respond by saying, "I'm not controlling you; I just want you to be safe!" This illustrates gaslighting in that the abuser is redefining reality to fit their own needs.

When a speaker uses redressive action to the addressee's negative face, they are engaging in creating social distance between the speaker and the addressee (Austin, 1990). In these instances, familiarity between the speaker and addressee would be appropriate. In fact, As a face attack strategy, it is typically used in situations where the hearer has either good reason to believe that there is a sufficient level of intimacy or a small enough power asymmetry that a more causal friendly style would have been expected. (Austin, 1990, p. 287) 
During on-record face attacks with inappropriate redress to the addressee's negative face, the speaker redefines the social distance between the two. As a result, the speaker also redefines the power distance, giving the speaker more power than the addressee. For example, an abuser might tell their partner "Please share your social media passwords with me. I just want to make sure that we are coordinating our messages." This strategy implies the addressee that they must adjust their behavior to meet the social requirements of the situation and thus is coercive (Austin, 1990). On-record attacks with inappropriate redress can humiliate the addressee by making the addressee feel as if they misinterpreted the closeness of their relationship with the speaker. The addressee has calculated the power distance between themselves and the speaker to be relatively small, but the speaker has shown them that their calculation is wrong.

Off-record. When choosing to engage in a face attack, the speaker will calculate the risk such an attack will have to their face (Austin, 1990). The more a speaker perceives a risk to their own face from a face attack, the more likely they will be to choose a strategy that mitigates the attack, such as an off-record approach. Off-record face attacks require the addressee to interpret the meaning of the utterance, relying heavily on the context and the mutual experiences of the speaker and addressee. For the addressee to understand the utterance, the context includes previous interactions between participants, preceding utterances, information available to the participants, and clues from the physical environment. Context plays a role in the interpretation of all of the face attack strategies to determine if the addressee will interpret the utterance as a face attack. However, context is the main determinant of off-record attacks. As a result of the attack being based on context and the relationship of the speaker and addressee, face attacks that are off-record may not be interpreted as such by other present parties. Off-record attacks may be used in abusive relationships when the partners are in public, allowing the attack to take place 
but only known to the couple. This can be even more complicated to interpret for the abused partner because their interactions with their abuser are constantly changing, meaning that the abused is unable to predict how their partner will react.

Austin (1990) states that there are three types of utterances that are classified as offrecord: hints, allusions, and irony. A speaker will use hints and allusions to focus the addressee's attention on facts, opinions, or values about which the addressee has strong opinions. The speaker will focus attention on these opinions as a way to attack the addressee's face. Attacks that are done in the form of hints or allusions can communicate private thoughts while in public. For example, when talking about their evening plans in the morning an abusive partner might keep their partner from having dinner with someone else by saying "Why don't we have dinner together tonight? I can make us a nice reservation. Jim will understand.” A speaker may use irony to give them a possible out if the attack goes badly (Austin, 1990). Irony is expressed in such a way that if it was used non-ironically, it would be sincere. However, in the context of a face attack, it is used in such a way as to convey a message to the addressee. A partner might claim to use irony in an interaction with their partner by stating "Dinner was terrible. You should only use my Mom's recipes." This way if the communication goes badly, the partner can claim that they were being ironic and make a joke about how their mom might be a terrible cook.

\section{Research Questions}

In sum, face attack acts utilize politeness strategies as a form of manipulation, coercion, and abuse. Emotionally abusive partners may utilize politeness through face attack acts to emotionally, financially, or socially harm their partner. Politeness through face attack acts can lend a theoretical understanding to how abusive partners manipulate politeness to continue their emotional abuse. 
The attention a speaker pays to face exists on a continuum from polite to impolite, and impoliteness strategies cannot be regarded as uncommon (Austin, 1990). Face attacks, whether targeted at positive or negative face, do not happen in isolation of each other. Austin (1990) explains, "All attacks on positive face (humiliation) have a secondary effect of coercion, as a humiliated [addressee] can be constrained to a small range of options for further behavior" (p. 289). Positive face attacks also attack negative face by limiting the actions of the addressee. This thesis will use Austin's (1990) face attack acts model and Brown and Levinson's (1987) politeness strategies to examine emotionally abusive relationships and answer the following research questions:

$\mathrm{RQ}_{1}$ : How, if at all, do polite messages result in abusive messages?

$\mathrm{RQ}_{2}$ : How, if at all, are polite messages a response to manipulative or controlling messages?

\section{Conclusion}

Brown and Levinson (1987) explained how communicators use politeness as a way to save the addressee's face. Austin (1990) took politeness a step further and explained how it can be used as a strategy for face attacks rather than saving face. Considering emotionally abusive relationships involve one partner threatening the other's face, using Austin's face attack strategies of politeness can lend an insight into emotionally abusive messages. 


\section{CHAPTER III: METHODS}

While interpersonal communication traditionally upholds quantitative and postpositivist research (Lindlof \& Taylor, 2011), a qualitative research design was the best for this study based on the research questions. Qualitative research is used "to understand the members' expertise, their worldview, or the interesting qualities of their culture" (p. 103). A qualitative research design provides a rich, detailed description of the human experience, including conversational encounters participants have had with others. Quality research within a qualitative research design is one in which a worthy topic is researched ethically to make a meaningful contribution (Tracy, 2010). With the complex issues surrounding victims of domestic violence, in-depth, qualitative interviews were the most appropriate for this study.

\section{Participants}

In-depth qualitative interviews were conducted with 20 individuals who self-identified as experiencing behaviors reflecting emotional abuse. Criterion sampling was used to ensure participants met the terms of the research study (Lindlof \& Taylor, 2011). In order to qualify for the study, participants were required to be at least 18 years old, have been in a romantic relationship in which their partners repeatedly used verbal messages that hurt their feelings or made them feel bad about themselves, and be comfortable speaking about their experiences. IRB approval was obtained before any participants were recruited for the study. Participants' age ranged from 18 to 55. Sixteen participants were female and four were male. Participants selfidentified their race, and 15 were White, two were Hispanic, two were a biracial mix, and one was Asian. Sexuality was also self-identified by participants, with 17 identifying as heterosexual, two as bisexual, and one as pansexual. Only one participant identified their former partner as having the same sex as themselves. 


\section{Procedures}

Participants were recruited through the Illinois State University communication research board and the study information was posted to my own Facebook page (See Appendices A through $\mathrm{C}$ for recruitment materials). Recruitment materials did not label the behaviors as emotional abuse. Instead, the materials stated specific behaviors that are considered emotionally abusive, such as the participant's partner repeatedly hurting their feelings, making the participant feel bad about themselves, or feeling controlled. Participants were required to contact the researcher directly through email if they wished to participate in the study. Once contacted, the researcher responded to participant emails with the requirements for participation and a consent form they read prior to attending the scheduled interview. Due to the sensitive nature of the topic, interviews could upset the participants, especially when recounting past traumatic experiences. In order to prevent distress, participants were made aware that they could exit the interview at any time and could choose not to answer any questions. This protocol was explained in the initial email to the participants as well as in the consent form. Before the interview began, the researcher asked for verbal consent (See Appendix D for informed consent).

A more informal, flexible approach was taken for the interviews using an interview guide (Lindlof \& Taylor, 2011) rather than a structured questionnaire (McCracken, 1988). Using an interview guide allowed for the participants to guide the interview (Lindlof \& Taylor, 2011) rather than treating each participant exactly the same (McCracken, 1988). Politeness theory was used to help develop the interview protocol. Prior to the interview, the participant completed demographic questions (e.g., What is your age? What is your gender? What is your sexuality?) and emailed a word document back to me (See Appendix F for the demographic survey). The first set of questions asked participants about their relationship with their former partners (e.g., 
How did you meet? How long was the relationship?). The next set of questions focused on the emotional abuse of the relationship (e.g., What are some messages or communication instances that your partner used that made you feel bad? How did you view your partner when they used these messages? How did you respond to your partner's messages?). The interview ended with questions on how the abuse has impacted the participant following the relationship (e.g., How have these hurtful messages you have experienced changed how you communicate, both with peers and other romantic partners?). The final question asked participants if there was anything they would like to add about their experiences with their partner (See Appendix E for interview protocol).

The interviews lasted between 20 and 55 minutes. Of the 20 conducted interviews, 17 were completed face-to-face and 3 used Zoom, a video chat format that allowed for video and audio recordings. However, only audio recordings were utilized. In fact, all interviews were audio recorded in order for them to be transcribed. Once verbatim transcriptions were completed, all of the recordings were deleted. All participants were given participant numbers in order to maintain confidentiality. The transcribed interviews resulted in 131 single-spaced pages.

\section{Data Analysis}

Thematic analysis was used to analyze the data collected from the interviews. Thematic analysis is used for "identifying, analyzing, and reporting patterns within data" (Braun \& Clake, 2006, p. 79). By using thematic analysis, I was able to "search for certain themes or patterns across an entire data set, rather than within a data item, such as an individual interview" (p. 81) allowing for the analysis of politeness found within emotional abuse. Braun and Clarke's (2006) explanation of thematic analysis called for a six-step process. Thematic analysis began with me familiarizing myself with the data, which started with transcribing the interviews then reading 
the data through twice. Next, I generated the initial codes. This step was completed twice. First, utterances were grouped using the a priori categories of face attack acts (utterances from abusers) and politeness categories (utterances from victims). Once the utterances were grouped into categories, emergent initial codes were identified directly from a segment of the transcript. After generating the initial codes, I moved onto the third step, where I grouped the emergent initial codes into potential themes. Then I reviewed the potential themes by checking them in relation to the initial codes and the data set as a whole. Once the themes were checked, I then defined and named the themes. The final step of the thematic analysis occurred when I wrote the report that summarizes the data.

For research question one, Austin's (1990) framework for face attack acts was used to categorize the data into one of the five strategies: bald-on-record with regard to positive face, bald-on-record with regard to negative face, on-record with inappropriate redress with regard to positive face, on-record with inappropriate redress with regard to negative face, or off-record. Brown and Levinson's (1987) politeness strategies were used to code for research question two by categorizing victim utterances into one of the four strategies: bald-on-record, on-record with redress to positive face, on-record with redress to negative face, or off record. I reached saturation after the $14^{\text {th }}$ interview; the rest of the interviews were coded to confirm redundancy.

\section{Conclusion}

The 20 participants completed semi-structured interviews in which I recorded their responses. After the interviews were completed, I transcribed each interview verbatim, resulting in 131 single spaced pages. The transcripts were then analyzed using Braun and Clarke's (2006) thematic analysis. Each utterance was first categorized using the a priori themes of face attack 
acts (Austin, 1990) or politeness strategies (Brown \& Levinson, 1987) before emergent themes were found within each categorization. 


\section{CHAPTER IV: RESULTS}

Brown and Levinson (1987) developed the theory of politeness as a way that speakers can save the face of their addressees in order to accomplish goals that would typically attack the face of the addressee. Austin (1990) argued that politeness strategies could be manipulated into face attack acts to attack the addressee's face rather than save it. Based on politeness theory and the face attack acts model, 20 semi-structured interviews were completed with victims of emotional abuse. The interviews were then analyzed, and reported utterances of abusers were categorized using the face attack acts model, while utterances of victims were categorized using politeness theory. Once categorized, emergent themes were found for each category.

In order to answer the two research questions, the data were analyzed using Austin's (1990) face attack acts model of politeness and Brown and Levinson's (1987) politeness theory categorizations. First, the strategies that were found to be used by abusers are discussed. Then, responses from victims to their abusers are described.

\section{Face Attack Acts Using Politeness}

Participants reported that abusers utilized each of Austin's (1990) strategies of politeness to manipulate, control, and ultimately abuse their partners. The phrases each abuser used were specific to the relationship they had with their victim. However, while each comment focused on the relationship, they fit larger themes that appeared throughout the data. Each of the politeness strategies will be described and followed by how abusers utilized that strategy.

\section{Bald-on-Record}

Victims reported the use of bald-on-record face attack acts from their partners more than any other strategy. These face attack acts require a level of dominance on behalf of the speaker, often found in abusive relationships. Bald-on-record acts attack the addressee's face without 
attempting to save face. Austin (1990) broke down bald-on-record face attacks into attacking either positive or negative face.

Positive face. Bald-on-record attacks that are geared toward an addressee's positive face communicate disrespect for the addressee. Victims report two themes used by their partners during positive face bald-on-record attacks: degrading comments and relationship fears.

Degrading comments. Degrading comments were used by the abuser to tear down the victim's sense of self. Abusers used obscenities and name-calling to degrade their partners. One participant said that her abuser would "just kind of call me names. He would call me 'bitch."” Meanwhile, another participant stated that "if he wanted to end the conversation he would just say 'fuck you' or like use cuss words at me." Another partner would tell their victim "Fuck you, I hate you." Abusers used obscenities and name-calling as a way to degrade their partners and tear down their sense of self.

Some partners focused their degrading comments on their partners' appearances. One participant described how her partner would use Instagram to degrade her: "He was scrolling through Instagram and showing me there really pretty, beautiful models and would say stuff like, 'If you looked like her, I would love you so much more." Another participant stated that her partner "would fat shame me to the point where he would say you know like, 'You look disgusting in that. You look like a hooker. You look fat. You look like a lazy bum.”’

Other abusers focused on attacking the victims' insecurities. One participant described how her partner would demean anything she did, even if it was to help him: "Everything I did, said, touched whatever, was wrong and bad and disturbed him. If I made food, he would make fun of it. Um, if I wanted to watch a show, it was stupid, he didn't want to see it." Meanwhile, earlier in the interview this participant sated: 
I wasn't very good at cooking and I wasn't, you know I was trying, I was tryin'. But everything was wrong, you know. Everything was wrong, everything was bad. If I didn't know something, he wouldn't help me, he would just slap the table and say "learn." This victim was insecure about her abilities to run the house or be a wife, yet her abuser used these insecurities as a way to demean her. Another participant described how they were insecure about how their relationship started with their abusive partner because the participant had hurt a friend in the process of forming the relationship. In order to make the victim feel bad, the abuser would tell her, "You're a bad friend. You're a bad person because of how we started." Comments like these went on-record as a way for abusers to tear down their partner's sense of self.

Relationship fears. Given the context of the communication, it appears that abusers also communicated their own fears about the relationship by using bald-on-record attacks that targeted the addressee's positive face. One abuser communicated her insecurities about her relationship to her partner by stating, "Well I guess you should just go date them" when her partner went to a party where other girls would be present. Meanwhile, another participant discussed how their partner would tell them:

"You're not trying hard enough." This is when I was in college. He would say, "You're not trying hard enough in this relationship, you don't do enough for me and this relationship, like you don’t care about me anymore."

An abuser told another victim, "All you wanna do is go out and you talk to guys all of the time." These abusers were insecure about their relationship. As a result of their insecurities, they used bald-on-record attacks that tore their partner down to communicate their fears. 
Negative face. To enact bald-on-record face attack acts directed at the addressee's negative face, abusers made demands of their partners. Abusers utilized two themes when engaging in bald-on-record face attacks focused on negative face: controlling messages and selfcentered demands.

Controlling messages. Participants reported that their abusive partner used controlling messages as a way to dictate what the victim's behavior should be. One participant stated that, when she was trying to terminate her relationship with her former partner, he told her "If you really want this to be over, then you have to break up with me face-to-face.” Rather than allowing the victim to end the relationship over the phone, the abuser controlled how the relationship ended to ensure it was on his terms. Another participant described an instance in which her partner had gone to a fast-food restaurant and received the incorrect order. When the participant offered to go and get the correct order, her abusive partner told her "If you walk out, don't ever come back" as a way to control her behavior. One participant's husband would use controlling messages to dictate her activities. She stated: "I was trying to teach myself guitar. He said, "I don't want to hear you play when I'm in the house." So, I stopped playing, cuz, because, you know, I was trying to do everything I could." One abuser would control his partner's actions by threatening self-harm: "He would threaten to commit suicide or something if I didn't get back with him." Another participant was told by her partner "Shut up! Stop talking! I'm tryin' to figure this out. Chill out." Abusers would engage in bald-on-record utterances geared towards attacking their partner's negative face in order to control their behaviors.

Self-centered demands. While controlling messages were used by abusers to control any behavior of their victim, self-centered demands were reportedly used by abusers to get their victim's behavior to benefit them. One participant struggling with her own mental health stated, 
If I had said things about me being depressed, it was like immediately shut down. She would say "this isn't about you" then just kinda like make me not talk about it anymore.

This abuser controlled her partner's disclosure of mental health issues to ensure that all of the attention was on herself. Another participant discussed how her partner responded to her going back to school. Rather than being supportive, the abuser told the victim they were not allowed to study at home because, "well, how are we interacting if you're so busy studying?" By telling the victim she could not study, he not only controlled her ability to receive a higher education but also ensured that all of her attention would be on him. Meanwhile, another participant discussed the sleeping arrangements in her relationship with her former husband, stating, "I had to sleep facing away from him--that's what he told me. He goes 'I don't want you breathing on me. I didn't want you touching me." Self-centered demands controlled the victims' behavior for the benefit of their abuser.

Hybrid messages. Brown and Levinson (1987) as well as Austin (1990) acknowledged the possibility of a message that might attack the addressee's positive and negative face simultaneously. One type of bald-on-record utterance included this hybrid strategy. One participant described her interaction where she questioned the choices of some of her husband's friends. The husband replied "You're wrong. You're stupid. You should not criticize my friends." This was a combination of a demeaning message as well as a self-centered demand. Another participant described an instance in which her partner told her "You're such a fucking slut. I can't even look at you. Get the fuck out of my face." Again, the abuser was using a demeaning message combined with a controlling message that attacked her positive and negative 
face. Abusers would go on record when they stated their criticism bluntly, attacking participant's positive and negative face to tear down the victim's sense of self and to control their actions.

\section{On-Record with Inappropriate Redress}

Participant interviews revealed that abusers utilized utterances that went on-record with inappropriate redress when they would state an utterance bluntly and then try to qualify it or soften it in some way. However, though they seemed to use a redressive action to save their partner's face, the statement of the redressive action still attacked the victim's face. Utterances that went on-record with inappropriate redress were common throughout the data but less common than bald-on-record responses. These responses still demonstrated the dominance of the abuser but did so in a way that made the abuse more covert. Like bald-on-record messages, onrecord messages either targeted the victims' positive face or negative face.

Positive face. When abusers would attack their partner's face and then tried to soften the attack, often using a hedge or a qualifier, the attack was usually centered on the victim's positive face. By using a hedge or qualifier, the abuser tried to engage in a redressive utterance. However, the redressive action did not save the victim's face; rather the inappropriate redress further attacked face.

The primary way that abusers were reported to use on-record messages with inappropriate redress to their partner's positive face was by excusing or justifying their messages. Buttny (1985) defined excuses as utterances in which the speaker admits that their message was hurtful, wrong, or inappropriate but denies full responsibility for the act. Meanwhile, justifications are used when the speaker accepts responsibility for the hurtful utterance but minimizes the hurtfulness of the message or claims that it has positive consequences (Koenig Kellas \& Suter, 2012). A White abuser repeatedly made jokes about the 
fact that her victim was Asian, even telling him, "Whoa, well no it's fine cuz it's a good thing cuz you're Asian, or whatever." This abuser was justifying her messages. When the victim did stand up to his abuser, she told him to "lighten up, it's a joke." Another abuser would excuse her utterances by saying, "I said this because you acted this way," putting the blame for the utterance on her partner. One abuser justified his desire for his girlfriend not to attend a concert by telling her, "Well, I don't like that band and so I don't wanna go, and I don't want you to go out with a friend because then you might go and find somebody better than me.” These abusers used onrecord responses with inappropriate address to justify their abusive messages to their partner. When abusers used excuses, they were attacking their victim's positive face by tearing down their sense of self. These justifications established that the victim's sense of self was for the abuser to comment on because it was a 'joke' or the victim's behavior warranted the hurtful message.

Negative face. Participants also described their partners using on-record messages with inappropriate redress that attacked their negative face. Austin (1990) described face attacks that were on-record with inappropriate redress as ones that created social distance between the speaker and the addressee. However, abusers did not use these face attacks to create social distance between them and their victim; rather, they used on-record utterances with inappropriate redress to create distance between themselves and their hurtful messages. The goal of on-record utterances with inappropriate redress toward negative face was to separate the abuser from their hurtful messages in the mind of the victim. Messages targeted at negative face were reportedly used by abusers to take away the victim's autonomy to leave the relationship, rather than pertaining to specific impositions. On-record messages with inappropriate redress were consistent with the gaslighting literature, where abusers make their partner question their sense 
of reality. On-record redresses toward a victim's negative face took away their control of their own realities. Abusers manipulated the victims' understanding of these messages by using defensive messages and apologetic messages.

Defensive messages. Defensive messages were reportedly used by abusers to defend their actions and words directed toward their partner as a way to make the victim question their understanding of the situation and of the abusive messages. Defensive messages included utterances such as "I didn't mean that. I didn't say that" and "Oh, I was just angry. I didn't mean it." However, one participant pointed out that her partner "would just tell me that I was interpreting it wrong," to defend his utterances. Another participant recounted that her abuser "called [her] sensitive a lot because [she] would, if [she] expressed any uncomfortableness with what he said." By defending their messages, abusers would attack their victims' negative face because they were not free to interpret the messages without imposition. Rather, their abuser would use defensive messages to defend their own negative face, ensuring that they were free of the repercussions of their own messages.

Apologetic messages. While defensive messages minimized the abusers' hurtful utterances, apologetic messages allowed the abuser to show remorse, before continuing the cycle of abuse by keeping the victim in the relationship (Walker, 1977). The cycle of abuse reported targets the victim's negative face by taking away their autonomy within the relationship and their ability to leave the relationship. However, that same cycle ensured that the abuser upheld their own negative face and remained free from imposition. One participant stated that her abuser would say, "I'm a jerk. I'm an asshole, I shouldn't have done that." This victim's abuser "would apologize, just his actions wouldn't change." The victim was under the impression that the apology meant that the abuser would change their behavior and chose to stay in the relationship, 
giving up their autonomy outside of the relationship. However, as this behavior continued, it was a further attack on the victim's negative face because she stayed in the relationship for him to continue to emotionally abuse her. Another victim stated that, after her boyfriend terminated the relationship, he reached out and stated, "It was very one-sided. I'm sorry. I'm sorry I hurt you." Once he was back in the relationship, the abuser went back to his abusive behaviors. One abuser told her partner "I really fucked up and I'm sorry." Meanwhile, another participant stated that her partner told her, “I'm sorry, that's not what I meant, it won't happen again.” Yet, after each of these apologetic messages, the abusive behavior continued. Apologetic messages threatened the victim's negative face because they forgave their abuser under false pretenses. By forgiving their partner, victims would give up their freedom and autonomy that they could find outside of their relationship, further attacking their negative face. Both defensive and apologetic messages were forms of redress; however, they did not save the victim's face. Rather these forms of redress furthered the abusive message by giving the abuser the victim's autonomy through the continuation of the relationship and abuse.

Hybrid messages. Like bald-on-record messages, abusers were reported to utilize utterances that went on record with inappropriate redress that targeted the victim's positive and negative face. Often these utterances would verbally attack the victim's positive face with the underlying subtext that would then control the victim's behavior and threaten their negative face (Austin, 1990). Specifically, abusers would critique their victim's appearance, focusing on makeup, clothing, and food choices in order to change future behavior focusing on these aspects of life. 
Abusers using hybrid critiques often included hedging or qualifying their comments because these strategies allowed them to frame the abusive message as if they were for the victim's own good. One abuser critiqued the makeup that their partner was wearing by stating Why did you have to do it that dark? You look so pretty with light makeup, like, it looks too dark. Why were you wearing that much makeup, like, who were you trying to impress? You always look better with light makeup on or you always wear makeup.

During this utterance, the abuser was using the qualification of telling his partner that she looked good in light makeup to critique the makeup she was wearing at the time of the interaction. Through this critique, the abuser was ensuring that his partner would wear makeup to his specifications in the future. Another white abuser told his Hispanic girlfriend who was wearing makeup that was too light for her skin tone, "Wow, you look better. You must've put on a lighter color." This quotation provides an example of a backhanded compliments; utterances that were posed as compliments that actually hurt the victim's positive face and then controlled their future behavior.

Other critiques on appearance centered on the victim's choice of clothing. One abuser would critique his victim's clothing by saying “if you respected me and yourself you wouldn't need to dress like this, like are you doing it for attention?" This abuser uses the qualification of respect for himself to critique the outfit that his partner is wearing while creating expectations for what she can wear later. Another abuser stated, "You look way too pretty in skirts. You shouldn't wear them around anyone else 'cuz you're too gorgeous" to critique the victim's clothing choices. By critiquing their partner's clothing choices using inappropriate redress, 
abusers not only attacked their positive face but controlled their behavior, ultimately attacking the victims negative face as well.

\section{Off-Record}

Off record responses are used when the speaker's meaning is sub-textual rather than blatant, for instance through hinting. Participants reported that abusers were the least likely to use off-record responses. Because of the dominance the abuser inherently had within the relationship, there was no need to rely on off-record utterances to save face. However, off-record utterances resulted in two themes: sarcasm or non-response.

Sarcasm. Through sarcastic responses, victims reported partners used humor to hint at the underlying message beyond the abuser's words. Abusers used sarcasm to convey their messages in a way that was more palatable to their victims. One participant stated that if she was having a good day her partner would say, “Oh, well aren’t you special?" as a way to "rain on [her] parade." Another participant discussed how her partner criticized her cooking by saying, "We're having chicken chips for dinner, lovely." One victim stated that "in 18 years together I think the only time he ever said the words 'I'm sorry' were sarcastically." These abusers utilized sarcasm to convey their hurtful messages to their partners without having to truly commit to their words.

Non-response. Brown and Levinson (1987) stated that a non-response was not engaging in a face threatening act, and therefore was not utilizing a politeness strategy, such as nonresponse. However, several participants discussed how their partners' lack of response was just as hurtful as their words. One participant discussed her abuser's behavior at parties stating, “Women would like openly flirt with him, they'd be touching him and stuff like that. And he just wouldn't do anything about it." This participant went on to further explain that "he would 
completely ignore [her] and go hang out with other people because he didn't want to be around [her], but he couldn't tell [her] no." One victim discussed her husband's nonresponse by stating Um when I was, I was going in for surgery, I was having my tonsils out and he said, 'I'm leaving on a 10-day trip.' He was a scuba diver, so he left the day of my surgery. It's not like I'm gonna call you to make sure you're okay or he never checked in those 10 days.

However, it was not just the abuser's actions that communicated abusive messages. Lack of positive communication was also provided as examples of abuse. For instance, a victim stated, "Um, he, I was never once complimented nor called beautiful, never called cute. I was - I never felt good. It's not the things that he said, it's the things that he never said." This abuser's lack of messages about her attractiveness communicated to her that he never found her particularly attractive. Non-response off-record messages appear to be as hurtful as any utterance.

In response to $\mathrm{RQ}_{1}$, abusers engaged in all five types of face attack acts of politeness laid out by Austin (1990). Each strategy resulted in themes of utterances that were spoken by abusers as a way to hurt, manipulate, or control their victims. Due to the power structure between abusers and their victims, abusers did not fear retribution. As a result, abusers engaged in bald-on-record face attacks. Abusers did not need to save their partners' face, so they did not need to waste the time and energy to protect their victims' face.

\section{Politeness Strategies}

While abusers utilized Austin's (1990) face attack acts, victims often responded to their partners using Brown and Levenson's (1987) politeness strategies to save their abusers' face. In response to research question two, victims used three of Brown and Levinson's politeness strategies. Victims did not go on-record with redress directed toward their abuser's negative face, 
meaning that these participants did not attack their partner's autonomy and, therefore, never had to engage in a redressive action. Victims did use off-record, on-record with redress toward positive face, and bald-on-record responses when communicating with their partner.

\section{Off-Record}

The most common politeness strategy that victims used is off-record responses by communicating their message sub-textually rather than bluntly. Considering that these individuals lacked dominance and power in the relationship, this was the safest response strategy for them to use. Off-record comments were used by victims in two ways: non-response and excuses.

Non-response. The most common response participants indicated using was nonresponse. Often these victims would walk away, stop communicating, or find some other way to not communicate. One participant used non-response to terminate the relationship stating, "I was in school. I had the chance to um go study abroad for a semester so um, I didn't tell him about that." In this case, this participant used non-response to physically leave her partner, eventually terminating the relationship. However, this was rare in the data.

Some participants used non-response to avoid creating or escalating conflict. More often, non-response was used to avoid or end the abusive messages that victims were receiving from their partner. One participant used non-response to keep from furthering the conflict. They stated, 'I'm not one to argue back, um, actually all of these, every single one that happened, I never said anything at all because I knew it would sorta fuel the fire, so I just sorta left it and it would die down and we would never talk about it again." Another participant said, 
I would never like voice my anger at him. I would never like like-we never actually fought. We never yelled at each other. It was a lot of like me just turning very passive cuz I knew that if I said anything like it would just get worse.

These participants used non-response to try to end or avoid the conflict with their partners' abusive messages.

Other participants would use nonresponse to avoid their partner's abusive messages. One participant stated, "I'd just get called annoying, so I tried not to speak a lot of the time." Another participant stated, “A lot of times she would send me paragraphs and I wouldn't even respond. I would be like, whatever." Both participants would avoid sending messages so that their partners had nothing on which to build abusive messages. A participant who was with her abuser for 11 years summed up the experience of non-response well when she stated, "You look for any way not to get into some sort of dialogue because you know it's going to be exhausting, and it's not going to end well, and it's not going to be pleasant."

Excuses. Victims would use excuses to save their abuser's face to the interviewer. Only one participant explicitly stated, "Um, I tried to just like take it like it was not like a real thing like she was just lashing out and she didn't mean any of it." Instead, excuses were implied in participants' talk about the abuse. For instance, one participant used the excuse of upbringing to justify her husband's behavior:

I really think that maybe he didn't realize what he was doing either because his dad was very verbally abusive to his wife. And I saw that when we would go to his house and you know, visit. Um they got divorced - his dad told his mom, "You know you're dumb, you're stupid." "What are you going to do?" You know, "Go ahead," you know, "leave me if you want. What are you going to do? You 
don't have any money." So he was kind of brought up with that background, so he would say similar kind of things. Um and probably didn't even think twice about it.

Another participant used a similar excuse, stating

Um he grew up with a father who was that way. Um, and I think, and his mom was real submissive to his dad and his dad made all of the decisions. His mom didn't have a choice in anything.

One participant was even more subtle in her excuses for her husband but still attributed his abusive behavior to a traumatic brain injury stating,

That was when the concussions, he would just--he has this thing where his heart rate, he has an arrhythmia as well as low blood pressure, and when the two would combine in just the wrong way, he'd pass out, and it took us quite a while to figure out what was causing him to pass out. So he couldn't get to a safe place. Of course, he passes out and cracks his head on concrete, and now he's got a concussion, and he hadn't been truthful with me because well, okay, he's a pathological liar, but if I wanna give him credit. He also said that he didn't wanna worry me as far as how often he was passing out. So, I was unaware for a very long time how often it was happening but it was definitely and that wasn't just my observation, that was also the observation of mutual friends that we'd had for our entire relationship. They noticed that yeah it was about that time.

Rather than saving their own face, or the face of their abuser during an interaction with them, victims were saving the abuser's face in the eyes of the interviewer. Abusers were not present, 
and, per the requirements of the study, participants were no longer in a relationship with them. However, participants felt the need to protect their abuser's face in the eyes of the interviewer.

\section{On-Record with Redress towards Positive Face}

Participants would occasionally respond using on-record messages with redress directed toward their abuser's positive face. Often participants described these responses as tactics to communicate with their partner while also diffusing the altercation. On-record responses with redress by victims resulted in two themes: apologies and redirection.

Apologies. Victims were often apologetic, trying to correct the error that they made in the eyes of their abusers. A participant whose partner would take out any frustration, even those outside of the relationship, on her stated, "If I did say something I would apologize and just say I'm sorry for giggling or I'm sorry for doing this even though deep down I knew it wasn't my fault." After a string of deaths of loved ones, one participant was confronted by his partner for being angry and hurt, he told her, 'It's like I'm sorry I don't mean to. I'm just trying to figure everything out with myself, you know. It's a lot to take in, in three months you know." During an altercation early in her pregnancy, one participant stated, "I remember that day just saying please stop. I'm pregnant, this is not what I said, please just stop. Like I love you." While this victim is not engaging in specific apologetic words, she was apologizing by clarifying "that is not what [she] said" and that she loved him. Victims would use apologies and apologetic language to calm down their partner, hoping that it would end the abusive interaction; however, it rarely did.

Redirection. One way that participants reported they would use on-record messages to respond to their partners was to redirect the altercation in some way. Sometimes an abuser would initiate altercations over text message, and the participant would respond by saying "This isn't a conversation we should have over like text, we should talk about this in person." This participant 
used an on-record message to redirect the communication into a less abusive one. Other participants would redirect by using questions. One participant stated, "I would usually ask a question back or I would always say why? You know something like that to try and figure out why she was saying, something like that." Other participants would ignore their partner's negativity in order to focus on the positive. One participant stated, "I would just respond with like positivity, this isn't what you mean. I wouldn't really acknowledge the negative parts and I would just like respond positively so it didn't further the negative conversation." Participants were going on-record by confronting their partner's messages, but they did so in a way that protected the abuser's face by redirecting the communication into safer territory.

\section{Bald-on-Record}

For victims, bald-on-record responses were used the least. Bald-on-record responses often signal dominance in the relationship, dominance that victims rarely have. However, baldon-record responses were occasionally used by victims; two themes were found: arguing back and termination.

Arguing back. Victims reported they would use bald-on-record responses to argue with their partners' hurtful messages. One participant stated that they "would go back off at him" while another occasionally responded to her husband by saying "that was rude." Another participant stated that if their abuser's message was “phrased in a calm or like passive-aggressive or like snippy way [she] usually would kind of get defensive and try to argue [her] opinions." When her partner would use on-record messages with inappropriate redress one participant said she would sometimes respond by telling him “you can't control what I wear and you can't, can't yell at me for what I wear." When her husband would berate her, one participant stated, "Every now and then at home I would you know respond and get angry or get upset." While getting 
angry or upset could simply be a cognitive response, in this case, the participant, placing it in terms of a "response" suggests that they communicatively expressed that anger as a response to an abusive statement. However, arguing back was not the norm.

Terminating. Out of the 20 participants, 13 victims were the ones who terminated the relationship. When these individuals terminated their relationships, they used bald-on-record messages to communicate the finality of their relationship. One participant stated, "At the end of our relationship when I broke up with him, I told him you know, you have been you verbally abused me. Um, you've done terrible things to me." This individual bluntly told her abuser that he was abusive. Another participant filed for divorce then terminated the relationship stating, "When I told him that I filed for divorce he was absolutely stunned. Absolutely shocked." A participant who also filed for divorce used bald-on-record messages to ensure her own safety during the legal process:

Our divorce was finished September $26^{\text {th }}$ of ' 19 , um, even though I left that December before, um, one day in April I had over 200 emails from him within a 12-hour period that were just insane. Um, but I had to ask my attorney to threaten to enforce the protective order with the divorce because he was harassing me and someone that I had started to date.

By asking the attorney to threaten a protective order, this participant used a bald-on-record strategy because she explicitly stated her intentions if her abuser's actions did not change. In order to end the relationship, these messages had to be bald-on-record.

If a participant did not use bald-on-record messages to terminate the relationship, they reported not being allowed to terminate the relationship. For example, one participant stated, 
So like whenever he threatened to kill himself if I broke up with him I just tried to focus on calming him down, talking him into being okay with it, maybe we can date in a few months, just trying to get him off the edge and I don't know just trying whatever I needed to do to get him to chill.

This victim was utilizing an on-record response with redressive action toward the abuser's positive face to end this relationship. For this participant, as Baxter (1984) explains, the abuser refused to accept her bid for termination resulting in negotiated escalation. Since the abuse continued, the result was not satisfactory, and the participant had to make her bid for termination more direct. This victim's abuser would not let her terminate the relationship unless she committed wholeheartedly to being blunt about the termination. If victims used any other politeness strategy to end the relationship, abusers would not accept it. As a result, participants had to use a bald-on-record strategy in order to end their relationship.

In response to $\mathrm{RQ}_{2}$ victims used three of the four politeness strategies outlined by Brown and Levinson (1987). Victims would respond using bald-on-record, on-record with redress toward positive face, and off-record politeness strategies. Participants rarely attacked their abuser's face and instead engaged in off-record strategies of politeness to a majority of abusive utterances to protect their abuser's face to the interviewer. When these victims did attack their partners' face directly, they usually did so by using redressive action meant to protect the abusers' positive face. Victims never attacked their partner's sense of autonomy, or negative face. When participants did engage in an attack on their abusers' face, they were most often engaging in relationship termination. 


\section{Conclusion}

In response to $\mathrm{RQ}_{1}$ participants reported that abusers utilized all of Austin's (1990) face attack acts: bald-on-record with respect to positive and negative face, on-record with inappropriate redress with respect to positive and negative face, and off-record. For $\mathrm{RQ}_{2}$ participants reported utilizing three of Brown and Levinson's (1987) four politeness strategies. Victims responded to their partner's abusive messages using bald-on-record, on-record with redress toward positive face, and off-record strategies. Politeness was manipulated by abusers in the form of face attack acts and victims utilized politeness strategies to try and communicate with their partners. 


\section{CHAPTER V: DISCUSSION}

The purpose of this study was to understand how those in emotionally abusive relationships utilize politeness. Both the abuser and the victim engage in politeness strategies as a way to communicate with their partner. Participants, who self-identified as former victims of emotional abuse, were asked to describe both their own as well as their partners' communication. I used Austin's (1990) face attack acts of politeness model to answer research question one which focused on abusers' use of politeness as a way to abuse their partners. I used Brown and Levinson's (1987) politeness theory to answer research question two about victims' use of politeness to respond to their partners. This study's findings will be summarized followed by the theoretical and practical implications and limitations of the study, with directions for future research.

\section{Summary of Findings}

From the semi-structured interviews, I categorized abusers' messages using Austin's (1990) face attack acts of politeness and victims' responses using Brown and Levinson’s (1987) politeness theory. After categorizing the utterances used by both abusers and victims, the messages were analyzed using thematic analysis. Each category of message, either from Austin's model or Brown and Levinson's theory, resulted in emergent themes.

\section{Face Attack Acts of Politeness}

Austin's (1990) face attack acts of politeness was the first and only research study to categorize politeness theory as a framework through which to view the way that an individual can hurt and manipulate their communication partners. In this study, Austin's model was applied to the verbal messages abusive partners sent to their victims over the course of the relationship. The data revealed that abusive partners engaged in all five face attack acts: positive and negative 
bald-on-record messages, positive and negative on-record messages with inappropriate redress, and off-record messages.

Bald-on-record messages were reportedly used by abusers to attack their victims outright. These messages were blunt, direct, and failed to engage in face saving strategies. Those bald-onrecord messages that focused on positive face communicated disrespect for the victim. Bald-onrecord messages directed at positive face resulted in two themes: degrading comments and relationship fears. Degrading comments attacked the victims' sense of self. Often, degrading comments included obscenities while criticizing the victims' self, regarding their appearance, or highlighting their insecurities. Bald-on-record messages seemed to communicate abusers' fears about the relationship. Often, messages that communicated relationship fears focused on how the victim was not doing enough for the relationship. By telling victims that they were not doing enough for the relationship, abusers communicated their fears of the relationship termination.

Abusers were also reported to use messages that were bald-on-record and attacked their victims' negative face. Bald-on-record messages directed toward attacking negative face resulted in messages that were demanding of the victim. These demanding messages resulted in two themes: controlling messages and self-centered demands. Controlling messages were used by abusers to demand that their partner act or behave in a certain way. Self-centered demands, like controlling messages, were meant to get the victim to behave as the abuser dictated. However, unlike controlling messages, self-centered demands were meant to get the victim to engage in behaviors that benefited the abuser specifically. Self-centered demands ensured that abusers were the ones who benefited from the relationship without regard to what it required of their partner.

On-record messages with inappropriate redress were reportedly used when abusers stated abusive messages then tried to explain the utterance in some way. These on-record messages 
upheld the dominance of the abuser while also making the abuse more subtle. Messages that were on-record with inappropriate redress directed at positive face used a hedge or a qualification for the abuser to excuse their abusive message. These justifications were used to defend the abuser's choice of words. This finding is similar to Wood's (2004) finding that men who engage in intimate partner utilized justifications to explain their physical abuse of their partners.

On-record messages with inappropriate redress towards negative face were reported by participants and used to create social distance between the abuser and their hurtful messages. Austin (1990) explained that on-record messages with inappropriate redress towards negative face were used to create social distance between the two speakers. In this study, abusers would distance themselves from their messages using redress, rather than creating social distance. Abusers distanced themselves from their messages by utilizing two themes: defensive messages and apologetic messages. Defensive messages were used to brush off the hurtful messages. Often abusers mentioned their outside emotional state as the reason that they said the things that they did, often brought on by something other than the victim. Apologetic messages were used by abusers to show remorse for their abusive messages. Defensive and apologetic messages were forms of inappropriate redress because it allowed the abuser to engage in gaslighting behavior and perpetuate the cycle of abuse (Walker, 1977).

By showing remorse, abusers perpetuated the cycle of abuse (Walker, 1977). The cycle of abuse starts with tension building when partners start using mildly hurtful messages. The tension comes to a climax, described by Walker as an acute battering instance, but in terms of emotional abuse, an instance of a deeply hurtful message. Then the abuse hits a lull in which there is a period of calm and loving, often when partners engaged in these apologetic messages. However, 
no matter how sorry the abuser was, the messages continued, following the cycle of abuse (Walker, 1977). However, similar to findings by Allen-Collinson (2011), participants in this study described being able to predict the abuse cycle; they knew when the tensions started building that they were heading for a climax of abuse.

Like bald-on-record messages, on-record messages with inappropriate redress attacked both a victim's positive and negative face, called a hybrid message. In this data, hybrid messages that were on-record with inappropriate redress were critiques of appearance. In order to critique appearance, abusers were reported to engage in a back-handed compliment based on the victim's appearance. These back-handed compliments made the victims feel bad about their current physical appearance or choices. However, sub-textually, by attacking the victim's negative face the abuser ultimately controlled the victim's future behavior. After these critiques the victims would conform to how their abuser wanted them to appear or dress.

While off-record messages were reportedly used the least by abusers, they were still found to facilitate emotional abuse. Abusers used two forms of off-record responses with their victims through either sarcasm or non-response. Sarcastic responses used humor to convey the abusive message to the victim. By using sarcasm, abusers could convey a hurtful message without having to commit to its meaning if the partner took it poorly. Abusers used non-response by openly omitting verbal responses that the victims expected to hear from a partner. By withholding these messages, abusers conveyed to their victims that they were never good enough to be in the relationship. As a result, the abuser framed themselves as being generous by being in a relationship with the victim. While abusers used Austin's (1990) face attack acts model, victims used Brown and Levinson's (1987) politeness strategies. 


\section{Politeness Theory}

Victims used Brown and Levinson's (1987) politeness strategies to respond to their abusive partners' messages. By utilizing politeness strategies, victims were trying to protect their abusers' face. While abusers engaged in all five types of face attack acts, victims only used three of the four politeness strategies: bald-on-record responses, on-record with redress toward positive face, and off-record responses.

While victims rarely reported using bald on-record responses, they occasionally engaged in this blunt message strategy to argue back or to terminate the relationship. Victims utilized onrecord responses with redress toward positive face in order to apologize to their abuser for the behavior that angered them. On-record responses with redress towards positive face were also used by victims to redirect the altercation in some way. Redirection resulted in the victim learning ways to divert their abuser's hurtful messages away from themselves. Sometimes participants described trying to be positive when their partner was engaging in negative abusive behaviors. Other participants would change the subject, engaging in anything that could divert their abuser's attention.

Victims, like abusers, reported utilizing non-response as an off-record strategy. However, rather than using off-record non-response to convey a message, victims used non-response to try and stop the altercation altogether and protect themselves from being further verbally abused. Victims felt that if they did not respond, their partner would eventually stop using verbally abusive messages. Beyond non-response, victims reported using off-record strategies to make excuses for their partner's behavior. These excuses, which often emerged in the interviews, were not part of victims' conversations with their abusers. Rather, victims were saving their abuser's face in regard to the interviewer. This was similar to Weathers, Sanderson, Neal, and Gramlich's 
(2016) findings of reasons why women stayed in abusive relationships. Weathers et al. found that women on twitter excused their abuser by placing responsibility for the abuse elsewhere, for instance on the abuser's difficult childhood, similar to the excuses produced by several victims in this study. By making excuses for their partners, victims justified the abusive behaviors that they were shown.

\section{Is Politeness Helpful?}

Based on Brown and Levinson's (1987) description of politeness, it could be assumed that politeness strategies would be able to help victims communicate with their partners (Yokotani, 2015). However, the present data set did not reveal a benefit to victims by using Brown and Levinson's politeness strategies. Rather, these victims were helped the most when they engaged in bald-on-record strategies to terminate the relationship. Of the 20 participants, 13 terminated the relationship. Engaging in the least polite and most blunt strategy helped those 13 individuals end their emotionally abusive relationship. The other politeness strategies did not lessen the abuse that victims faced and instead seemed to place the responsibility of lessening the abuse on the victims, for instance when they tried to redirect the conversation. As a whole, politeness did not protect victims of emotional abuse; the dominance disparity appeared to be too great for politeness to be of any consequential help.

\section{Theoretical Implications}

Considering this study was designed around Brown and Levinson's (1987) politeness theory and Austin's face attack acts, theoretical implications were found. Theoretical implications about politeness theory center on applying this theory to dark-sided communication, hybrid responses, and non-response as a form of off-record politeness. 


\section{Applying Politeness to Dark-Sided Communication}

Brown and Levinson's (1987) politeness theory was used to explain how people engage in critiques, criticisms, or demands in order to accomplish communication goals. By utilizing politeness, those who use these strategies work to save their addressee's face. As a result, politeness theory is inherently a bright-sided communication theory. Many of the politeness strategies attempt to save face, accomplish goals, and leave both parties relatively satisfied with the communication. Even though bald-on-record strategies are seen as not saving face, the relationship or context in which they tend to be used usually justify their usage. When two communication partners are close, their relationship allows bald-on-record messages without challenging their addressee's face (Austin, 1990). Similarly, during emergencies, bald-on-record messages are efficient, and therefore any face needs are overruled by the situation.

Austin (1990) established how politeness can be used for dark-sided acts. Other than bald-on-record approaches, Brown and Levinson's (1987) strategies were meant to save face. In Austin's article, face attack acts used the same strategies Brown and Levinson outlined to save face but this time as a way to attack the addressee's face. Although Austin created the framework, it was not until the present study that politeness was applied to dark-sided communication phenomena.

In this study, I took Brown and Levinson's (1987) theory and Austin's (1990) model to apply these politeness strategies to emotionally abusive relationships. By utilizing politeness as a framework, this study has established that politeness can be, and is, manipulated as a form of emotional abuse. It was expected that the most common strategy used by abusers would be baldon-record. However, many of the strategies used by abusers utilized on-record with redress or off-record strategies as a way to attack their victims' face while also seeming to save face. These 
messages appear on the surface to be polite and caring, but in reality, they have a deeper meanings that attack the addressee. This research expands the literature on politeness theory. Traditionally scholars treat politeness as a way to show concern for the addressee's face during interactions. Politeness allows partners to try to save face while still attending to the task or goal they are trying to achieve. However, in this instance, participants perceived that their abusers' goal was to abuse, cause emotional harm, or hurt the victim. By using politeness, abusers were able to accomplish their goals. Using the frame of politeness allows us to see how partners can engage in covert abuse by appearing or pretending to be concerned for their partner's face while at the same time threatening it, making it very difficult for a victim to make sense of the messages they are receiving and possibly for others to identify the messages as abusive. This could be similar to Bateson, Jackson, Haley, and Weakland's (1956) 'double bind' (though described for schizophrenia) where an individual is placed in a situation they cannot win. Victims experiencing polite emotional abuse may experience this 'double bind' in which they cannot win when it comes to their abusive partner.

\section{Hybrid Messages}

Most utterances by both abusers and victims were either directed at positive or negative face. However, some messages were a combination of both positive and negative face attacks, such as those that critiqued appearance. The data revealed this anomaly only in face attack acts used by abusers. Often these hybrid messages attacked the victim's positive face and sense of self in order to attack their negative face and get them to comply with an action that benefited the abuser. A single utterance often targeted at the positive face can simultaneously attack negative face and control an individual's behavior. 
Hybrid messages allow an abuser's words to focus on the victim's positive face while simultaneously using that attack to control the victim's behavior. These messages allow a partner to gaslight their victim by denying the victim's reality (Stark, 2019). For example, if a partner confronts their abuser about how they control their behavior, such as clothing, by using hybrid messages, the abuser can deny that they ever did that. Abusers can deny that they controlled their victim's behavior because their words centered on something entirely differently, perhaps through a back-handed compliment they believe should be perceived as positive. Using hybrid strategies seems to allow abusers to create their own reality. Once an abuser creates the reality, they have full control over their victim. Hybrid messages make it even easier for abusers to gaslight their victims and establish reality as they wish it to be, because a single utterance can accomplish the abuser's goals.

Considering that this hybrid message was only to be used by abusers, it might be that only abusers utilize attacks on positive face to then attack negative face. Brown and Levinson's (1987) theory outlined hybrid strategies as "somewhere in between the two" (p. 230) types of face, and Austin's (1990) model mentioned hybrid tactics. This anomaly requires future research to understand how and when individuals engage in hybrid politeness messages in order to utilize face attack acts. Do other populations and other communication phenomena engage in hybrid messages as well? Further research is necessary to understand how politeness is utilized in a hybrid manner.

\section{Non-Response as an Off-Record Tactic}

Previous literature (Brown \& Levinson, 1987) describes a non-response as failing to engage in a face threatening act and therefore, not using politeness. However, Watzlawick, Beavin, and Jackson argue that "one cannot not communicate" (p. 49). Based on this statement, 
even the lack of response communicates a message. As a result, not engaging in a face threatening act, communicates a message to addressees and should be regarded within politeness strategies. This study has established that a non-response is a form of going off-record. The victims' use of non-response did not contain a message that was particularly salient. When victims described their own non-response, to their understanding this did not seem to hurt their partner. However, participants perceived that abusers utilized non-response as a way to communicate to their victims they were not good enough for the relationship. By engaging in non-response as a form of off-record messages, abusers communicated to their victims that they were not even worth a response or hurtful message. Without ever using words, abusers were able to convey the meanings they wished to their partners while also saving their own face, because technically they never said anything hurtful. Future politeness literature should include nonresponse as an off-record tactic because it can contain just as much meaning as a verbal message. Such meaning should be considered within the literature.

\section{Practical Implications}

Due to this study's nature in examining emotionally abusive relationships, this research has resulted in practical implications. Throughout the 20 participant interviews, five of the six forms of emotional abuse described by Follingstad et al. (1990) were found. The data revealed that abusers used verbal attacks, isolation, jealousy and possessiveness, emotional blackmail, and denying the abuse or blaming the victim for the abuse. The only form of abuse that was not found were verbal threats. However, this form of emotional abuse could have been omitted by participants considering that I was required to report any threats of abuse for any participant affiliated with my university, and I conveyed that requirement to participants before the study. All five forms of abuse utilized at least one of Austin's (1990) strategies in the face attack act 
model of politeness. This research has practical implications in counseling, preventative interventions, and the cycle of abuse (Walker, 1977).

This research can help guide those who counsel victims of emotional abuse. Categorizing emotional abuse using the face attack acts of politeness (Austin, 1990) can help counselors guide their patients through a deeper understanding of emotional abuse. One participant, a woman in her 50s, discussed how at the time of her relationship, she did not consider her relationship as abusive because there was not a language of emotional abuse. While the Follingstad et al. article was published in 1990 followed by Pence and Paymar's 1993 article, it took several more years for the understanding of emotional abuse to reach the public. Today, emotional abuse is known within mainstream American culture even if it is not protected by the law. In fact, several participants responded to questions during the interview asking if I meant "gaslighting," an indication that the vernacular has become part of laypeople language. When counselors, psychologists, and psychiatrists understand that emotional abuse can be polite, yet still abusive, they can help patients understand that what they experienced was in fact, emotional abuse. As mental healthcare providers start to incorporate this deeper understanding of emotional abuse into their practices, the more that this understanding of the polite abuser will seep into the mainstream understanding of what is emotional abuse.

Future emotional abuse intervention should teach individuals to evaluate emotional abuse based on how the utterance makes them feel. This research revealed that it is not what the messages says, or how it is interpreted that makes a message abusive. What makes the message emotionally abusive is what it means in the context of the relationship. As a result, interventions in the form of trainings, seminars, or therapy should classify emotional abuse based on how it makes the individual feel. This will allow victims to understand the abuse they are facing, 
allowing them to verbalize their experiences, and hopefully lead them to help sooner rather than later.

Interventions should teach that emotional abuse can be polite for the benefit of abusers as well. Although abusers were not interviewed for this study, as they were in Wood's (2004) study, they may not have viewed their messages as abusive. The abuser might have perceived what they were saying as just a joke or even as a compliment much like Wood's finding in which participants not only justify their actions but dissociate from them as well. When participants disassociated, they disconnected themselves from the violence they perpetrated. Similarly, the abusers in this study may argue, their victim may just be overreacting because they were being polite, after all. By incorporating politeness into emotional abuse interventions, abusers can come to recognize their messages as abusive. For some abusers, this will not change their actions because they set out to abuse their partner. However, many might mistakenly think that their communication is healthy. Once these individuals know that their communication, though polite, can be abusive, they might change how they speak to and communicate with their partner.

Walker published the cycle of abuse in 1977; it has not been updated since. As was just stated, the understanding of abuse has drastically shifted since the 1990s and even more so since the 1970s. However, the cycle of abuse has failed to keep up with the various forms of abuse that have come to be accepted since 1977. This research is an update to Walker's cycle on physical abuse by establishing that emotional abuse, like physical abuse, follows a cycle that victims can come to predict. While continued research is needed to understand if emotional abuse follows the same cycle of tension building, climactic outbreak, and loving reprieve, this research did establish that there is, in fact, an emotional abuse cycle. The development of a description of the cycle of emotional abuse can guide future research. 


\section{Limitations}

The findings in this study must be interpreted in light of some limitations. First, this was a predominately white, female, and young sample. Of the 20 participants, 16 were female, 15 were white, and 12 were under the age of 25 . While eight participants were 25 years or older at the time of the interview, only two of the relationships occurred after the participant turned 25 . In fact, only 11 relationships occurred after the participant turned 18. Therefore, a majority of the relationships that the participants described occurred during high school. Considering I recruited from a medium-sized midwestern campus, these demographics were unsurprising. However, an older more diverse sample could have resulted in a more nuanced use and understanding of politeness in emotional abuse.

This sample might have been predominately female because it is culturally acceptable for women to have experienced emotional abuse. The cultural views of masculinity may leave many men who have experienced similar abuse as my participants without an understanding that they experienced emotional abuse — or less willing to talk about such abuse in an interview. As a result, more women, who have had the support to process their experiences, were able to selfselect in order to be a participant. Young men, who do not have the same support and understanding when it comes to emotional abuse, may have felt that by self-selecting to become a participant they were damaging their own positive face. In fact, Lisak (1994) found that male survivors of sexual abuse viewed victimization as a threat to their masculinity. The understanding of masculinity, though it is 2020, is not as accepting of male victims, particularly male victims of emotional abuse.

The second limitation is regarding mandatory reporting. At the university in which I conducted this research, I am a mandatory reporter. Because of my reporter status, I am required 
by law to report any instances of physical violence, sexual assault or harassment, or threats of violence or assault of any student to the Title IX office. As a result, I designed this study to ensure that participants did not disclose information that required me to report. However, this meant that some participants could not answer or elaborate on the questions that I asked. While emotional abuse often includes physical abuse, I was required to keep participants focused on verbal messages to ensure that the interview remained confidential. Without this restriction, a better understanding of how physical and emotional abuse interacts with each other might have been found. For the three participants who were not students at my university, the interviews appeared to be less restricted, and they were able to describe their fears that emotional abuse was just the beginning.

\section{Future Research}

Future research should examine politeness in a more diverse population, especially in adult relationships. Relationships that take place once emerging adults reach full adulthood may result in different portrayals of emotional abuse. Older individuals in long term committed relationships should be studied because how politeness is used and manipulated may unfold differently than in this sample. However, because this was so prevalent in high school populations, interventions should be developed to educate younger students on emotional abuse.

How nonverbal behaviors contribute to emotional abuse also merits further research.

Often politeness relies on these nonverbals, such as tone of voice, which are not characterized by Brown and Levinson (1987). Future research should explore how emotional abuse manipulates nonverbals during polite messages to be a face attack act (Austin, 1990) rather than a face-saving strategy. 
Scholars who use politeness theory should also examine how bystanders who witness emotional abuse respond to problematic communication. Victims rely on social support to recognize emotional abuse, terminate the relationship, and deal with lasting trauma. However, politeness helps abusers "cover up" their emotional abuse and may make abuse even more difficult for bystanders to recognize as abusive. As a result, bystanders may deny the victim's concerns about emotional abuse, leaving the victim without social support. Further research is needed to understand how those who witness emotional abuse respond.

Hybrid messages must be researched further. It could be that this data produced an anomaly in the form of a hybrid message that attacked both positive and negative face, or it could be that only abusers utilize this strategy when engaging in face attack acts. However, future research should explore hybrid politeness strategies to understand how and when they are used. Hybrid responses may only exist within a politeness strategy that is oriented towards both positive and negative face. However, hybrid responses might exist when speakers blend two politeness strategies together. Further research is needed to understand how and when hybrid messages occur.

Walker's (1977) cycle of abuse should be updated to include the emotional cycle of abuse. One participant stated,

it got to where I would see, I got to see the cycle of the abuse and could almost predict when it was going to happen. Um, so I, I started to kinda change, at first I started to change my reaction um because I knew something was going to happen so okay, let's try it this way, don't speak up cuz if I speak up then he treats me like crap and he's mean and I get scared and I lock myself in the guest room. Or if I speak up maybe eventually he'll stop. So I tried different approaches um, um, 
none of them ever seemed to change anything. I just knew that whenever I did speak up it was always going to have the exact same reaction, so it got to be very predictable and I kind of saw him in this untrustworthy um, predictable abusive way.

The cycle of emotional abuse should be empirically studied in order to establish if the cycle is the same or different than that of physical abuse. Once the cycle of emotional abuse is established, Walker's cycle of abuse may need to be updated to incorporate the various forms of abuse. Patterns are important and allow victims to understand and recognize what is happening or what has happened to them. Updating Walker's cycle of abuse may be the first step in helping achieve the practical implications of this study.

\section{Conclusion}

Over the decades, what is considered abuse has expanded. No longer is abuse defined only in terms of physical violence from one partner, usually the man, to another partner, usually the woman. Rather abuse can be perpetrated by any individual regardless of sex, gender, or sexual orientation. In this study, I established that emotional abuse can look and sound like polite communication while actually communicating something entirely different, something much more harmful and dark-sided. 


\section{REFERENCES}

Abowitz, D. A., Knox, D., \& Zusman, M. (2010). Emotional abuse among undergraduates in romantic relationships. International Journal of Sociology of the Family, 36(2), 117-138. Retrieved from https://www.jstor.org/stable/23028825

Abramson, K. (2014). Turning up the lights on gaslighting. Philosophical Perspectives, 28(1), 130. doi:10.1111/phpe. 12046

Aizer, A. (2011). Poverty, violence and health: The impact of domestic violence during pregnancy on newborn health. Journal of Human Resources, 46(3), 518-538. doi:10.1353/jhr.2011.0024

Allen-Collinson, J. (2011). Intimate partner abuse and the contestation of identity. Symbolic Interaction, 34(1), 108-127. doi:10.1525/si.2011.34.1.108

Austin, P. (1990). Politeness revisited: The dark side. In Bell, A \& Holmes, J. (Eds.), New Zealand ways of speaking English (pp.277-297). Clevedon, England: Multilingual Matters.

Bastian, B. (2019). A dehumanization perspective on dependence in low-satisfaction (abusive) relationships. Journal of Social and Personal Relationships, 35(5), 1421-1440. doi: $10.1177 / 0265407519835978$

Bateson, G., Jackson, D. D., Haley, J., \& Weakland (1956). Toward a theory of schizophrenia. Behavioral Science, 1(4), 251-254. Retrieved from http://www.psychodyssey.net/wpcontent/uploads/2012/05/TOWARD-A-THEORY-OF-SCHIZOPHRENIA.docx

Baxter, L. (1984). Trajectories of relationship disengagement. Journal of Personal and Social Relationships, 1, 29-48. doi:10.1177/0265407584011003 
Black, M. C., Basile, K., Breiding, M., Smith, S., Walters, M., Merrick, M., .. . Stevens, M. (2011). The National Intimate Partner and Sexual Violence Survey (NISVS): 2010 summary report. Atlanta, GA: National Center for Injury Prevention and Control, Centers for Disease Control and Prevention.

Braun, V. \& Clarke, V. (2006). Using thematic analysis in psychology. Qualitative Research in Psychology, 3, 77-101. doi:10.1191/1478088706qp063oa

Brewer, G. \& Abell, L. (2017). Machiavellianism, relationship satisfaction, and romantic relationship quality. Europe's Journal of Psychology, 13(3), 491-502. doi:10.5964/ejop.v13i3.1217

Brown, H. (2018). Fictional power and control and the reality of abusive behavior. Journal of Gender Studies, 27(4), 401-410. doi:10.1080/09589236.2016.1223611

Brown, P., \& Levinson, S. (1987). Politeness: Some universals in language usage. Cambridge, England: Cambridge University Press.

Buttny, R. (1985). Accounts as a reconstruction of an event's context. Communication Monographs, 52, 57-77. doi:10.1080/03637758509376095

Byers, L. A., Shue, C. K., \& Marshall, L. L. (2004). The interplay of violence, relationship quality, commitment and communication in abusive relationships. Texas Speech Communication Journal, 29(1), 43-51. Retrieved from https:/www.etsca.com/journal.asp

Coscarelli, J. \& Ryzik, M. (2019, February 13). Ryan Adams dangled success. Women say they paid a price. The New York Times. Retrieved from https://www.nytimes.com/2019/02/13/arts/music/ryan-adams-women-sex.html 
Cross, C., Dragiewicz, M., \& Richards, K. (2018). Understanding romance fraud: Insights from domestic violence research. The British Journal of Criminology, 58(6), 1303-322. doi:10.1093/bjc/azy005

Dillard, J. P., Wilson, S. R., Tusing, K. J., \& Kinney, T. A. (1997). Politeness judgments in personal relationships. Journal of Language and Social Psychology, 16(3), 297-325. doi:10.1177/0261927X970163003

Dorpat, T. L. (1994). On the double whammy and gaslighting. Psychoanalysis and Psychotherapy, 11(1), 91-96. Retrieved from https://psycnet.apa.org/record/1995-25157001

Dragiewicz, M., Burgess, J., Matamoros-Fernàndez, A., Salter, M., Suzor, N. P., Woodlocks, D., \& Harris, B. (2018). Technology facilitated coercive control: Domestic violence and the competing roles of digital media platforms. Feminist Media Studies, 18(4), 609-625. doi: $10.1080 / 14680777.2018 .144734$

Ebbeler, C., Grau, I., \& Banse, R. (2017). Cultural and individual factors determine physical aggression between married partners: Evidence from 34 countries. Journal of CrossCultural Psychology, 48(7), 1098-1118. doi:10.1177/0022022117719497

Fletcher, M. A. (2018). We to me: An autoethnographic discovery of self, in and out of domestic abuse. Women's Studies in Communication, 41(1), 42-59. doi:10.1080/07491409.2017.1423526

Follingstad, D. R., Rutledge, L. L., Berg, B. J., Hause, E. S., \& Polek, D. S. (1990). The role of emotional abuse in physically abusive relationships. Journal of Family Violence, 5(2), 107-120. doi:10.1007/BF00978514 
Gass, G. Z. \& Nichols, W C. (1988). Gaslighting: A marital syndrome. Contemporary Family Therapy, 10(1), doi:10.1007/BF00922429

Goffman, E. (1959). The presentation of self in everyday life. Garden City, NY: Doubleday Anchor Books.

Grady, C. (2019, February 14). Multiple women, including Mandy Moore, have accused musician Ryan Adams of emotional abuse. Vox. Retrieved from https://www.vox.com/culture/2019/2/14/18224960/ryan-adams-mandy-moore-emotionalabuse-sexual-misconduct

Gormley, B. \& Lopez, F. G. (2010). Psychological abuse perpetration in college dating relationships: Contributions of gender, stress, and adult attachment orientations. Journal of Interpersonal Violence, 25(2), 204-218. doi:10.1177/0886260509334404

Hamby, S. (2016). Self-report measures that do not produce a gender parity in intimate partner violence: A multi-study investigation. Psychology of Violence, 6(2), 323-335. doi:10.1037/a0038207

Johnson, D. I., Roloff, M. E., \& Riffee, M. A. (2004). Politeness theory and refusals of requests: Face threats as a function of expressed obstacles. Communication Studies, 55(2), 227238. doi:10.1080/10510970409388616

Karakurt, G. \& Silver, K. E. (2013). Emotional abuse in intimate relationships: The role of gender and age. Violence and Victims, 28(5), 804-821. doi:10.1891/0886-6708.VV-D-1200041

Kaukinen, C. (2004). Status compatibility, physical violence, and emotional abuse in intimate relationships. Journal of Marriage and Family, 66(2), 452-471. doi:10.1111/j.17413737.2004.00031.x 
Koenig Kellas, J. \& Suter, E. A. (2012). Accounting for lesbian-headed families: Lesbian mothers' responses to discursive challenges. Communication Monographs, 79(4), 475498. doi:10.1080/03637751.2012.723812

Lammers, M., Ritchie, J., \& Robertson, N. (2005). Women's experience of emotional abuse in intimate relationships: A qualitative study. Journal of Emotional Abuse, 5(1), 29-64. doi:10.1300/J135v5n01_02

Leisring, P. A. (2013). Physical and emotional abuse in romantic relationships: Motivation for perpetration among college women. Journal of Interpersonal Violence, 28(7), 1437-1454. doi:10.1177/0886260512468236

Lindlof, T. R., \& Taylor, B. C. (2011). Qualitative communication research methods $\left(3^{\text {rd }} \mathrm{ed}\right)$. Thousand Oaks, CA: SAE Publications, Inc.

Lisak, D. (1994). The psychological impact of sexual abuse: Content analysis of interviews with male survivors. Journal of Traumatic Stress, 7(4), 525- 548. doi:10.1002/jts.2490070403

Lutgen-Sandvik, P. (2003). The communicative cycle of employee emotional abuse: Generation and regeneration of workplace mistreatment. Management Communication Quarterly, 16(4), 471-501. doi:10.1177/0893318903251627

Mathews, A. (2016, 26 September). When is it emotional abuse? Psychology Today. Retrieved from https://www.psychologytoday.com/us/blog/traversing-the-innerterrain/201609/when-is-it-emotional-abuse

McCracken, G. (1988). The long interview (13 ${ }^{\text {th }}$ ed). Newbury Park, CA: SAGE Publications, Inc.

Moore, J. (2017). Performative face theory: A critical perspective on interpersonal identity work. Communication Monographs, 84(2), 258-276. doi:10.1080/03637751.2017.1315891 
National Coalition Against Domestic Violence (n.d.). Domestic violence. Retrieved from https://www.speakcdn.com/assets/2497/domestic_violence2.pdf

Pence, E., \& Paymar, M. (1993). Education groups for men who batter. New York, NY: Springer.

Pizzirani, B. \& Karantzas, G. C. (2019). The association between dehumanization and intimate partner abuse. Journal of Personal and Social Relationships, 36(5), 1527-1541. doi:

\section{$10.1177 / 0265407518811673$}

Police are recording more domestic abuse against men. (2018, December 15). The Economist. Retrieved from https://www.economist.com/britain/2018/12/15/police-are-recordingmore-domestic-abuse-against-men

Rudd, J. E. \& Burant, P. A. (1995). A study of women's compliance gaining behaviors in violent and non-violent relationships. Communication Research Reports, 12(2), 134-144. doi: $10.1080 / 08824099509362049$

Stark, C. A. (2019). Gaslighting, misogyny, and psychological oppression. The Monist, 102, 221235. doi: 10.1093/monist/onz007

Stonard, K. E., Bowen, E., Walker, K., \& Price, S. A. (2017). “They'll always find a way to get to you": Technology use in adolescent romantic relationships and its role in dating violence and abuse. Journal of Interpersonal Violence, 32(14), 2083-2117. doi: $10.1177 / 0886260515590787$

The National Domestic Violence Hotline. (n.d.). Get the facts and figures. Retrieved from https://www.thehotline.org/resources/statistics/

The United States Department of Justice. (n.d.). Domestic violence. Retrieved from https://www.justice.gov/ovw/domestic-violence 
Tracy, S. J. (2010). Qualitative quality: Eight "big-tent" criteria for excellent qualitative research. Qualitative Inquiry 16(10), 837-851. doi:10.1177/1077800410383121

Walker, L. E. (1977). Battered women and learned helplessness. Victimology, 2(3-4), 525-534. Retrieved from https://psycnet.apa.org/record/1979-08581-001

Watzlawick, P, Beavin, J., \& Jackson (1967). Pragmatics of Human Communication. New York, New York: W. W. Norton \& Company, Inc.

Weathers, M. R., Sanderson, J., Neal, A., \& Gramlich, K. (2016). From silence to \#WhyIStayed: Locating out stories and finding our voices. Qualitative Research Reports in Communication, 17(1), 60-67. doi:10.1080/17459435.2016.1143385

Whitaker, D. J., Haileyesus, T., Swahn, M., \& Saltzman, L. S. (2007). Differences in frequency of violence and reported injury between relationships with reciprocal and nonreciprocal intimate partner violence. The American Journal of Public Health, 97(5), 941-947. doi:10.2105/AJPH.2005.079020

Wood, J. T. (2004). Monsters and victims: Male felons' accounts of intimate partner violence. Journal of Social and Personal Relationships, 21(5), 555-576. doi: $10.1177 / 0265407504045887$

Wozolek, B. (2018). Gaslighting queerness: School as a place of violent assemblages. Journal of LGBT Youth, 15(4), 319-338. doi:10.1080/19361653.2018.1484839

Yokotani, K. (2015). Links between impolite spousal forms of address and intimate partner violence against women. Journal of Language and Social Psychology, 34(2), 213-221. doi:10.1177/0261927X14551610 
Zavala, E. \& Guadalupe-Diaz, X. (2018). Assessing emotional abuse victimization and perpetration: A multi-theoretical examination. Deviant Behavior, 39(9), 1515-1532. doi:10.1080/01639625.2018.1491700

Zavala, E. \& Spohn, R. E. (2010). Emotional abuse and controlling behaviors in heterosexual relationships: The role of employment and alcohol use for women and their partners. Sociological Spectrum, 30, 526-549. doi:10.1080/02732173.2010.496103 


\section{APPENDIX A: RESEARCH BOARD RECRUITMENT}

If you have been in a former romantic relationship where your partner repeatedly sent or said messages that hurt your feelings, made you feel bad about yourself, or made you feel controlled are comfortable speaking about the messages, and are at least 18 years old, please email Cimmiaron at cpalvar@ilstu.edu to schedule your interview. With your permission, I will audio record the interview and I will delete the recording once I transcribe the interview. I will also change your name on the final thesis. 


\section{APPENDIX B: EMAIL RECRUITMENT}

Dear

I am a graduate student in the School of Communication and am conducting a research study to better understand how problematic messages are communicated in romantic relationships for my master's thesis. If you have been in a former romantic relationship where your partner repeatedly sent or said messages that your feelings, made you feel bad about yourself, or made you feel controlled and are comfortable speaking about the disclosure, and are at least 18 years old, then I request your participation.

You are invited to participate in an interview study regarding the communication from your former partner that hurt your feelings and/or made you feel bad about yourself. The interview may take place via phone, Facetime or Skype, or in person. Particularly, this study seeks to understand how problematic communication takes place in romantic relationships.

The interview will take approximately one hour. It will be confidential (I will not share your identity with others), except in instances of dating violence. I will change your name on the final paper for this project. Your participation will be completely voluntary. You may decide not to answer any question, and you can stop the interview at any time. All questions will focus on conversations about sexual assault disclosure, not on the assault itself.

Please direct any questions and/or comments to my thesis advisor, Dr. Aimee Miller-Ott (aeott@ilstu.edu), or to me.

If you would like to participate, please contact me at the e-mail address below.

Sincerely,

Cimmiaron Alvarez

Graduate Student, School of Communication

Illinois State University

cpalvar@ilstu.edu 


\section{APPENDIX C: FACEBOOK RECRUITMENT POST}

I am conducting a study for my thesis to better understand how problematic messages are communicated in romantic relationships. I'm not asking people to speak about any physical interactions with your former partner. Instead, I'm interested in how former partners communicate problematic messages that hurt their partner or make their partner feel bad about themselves. I am doing face-to-face, phone, or Skype/Facetime interviews that should last around one hour.

To participate, you have to have been in a former romantic relationship where your partner repeatedly sent or said messages that hurt your feelings, made you feel bad about yourself, or made you feel controlled and you must be 18 years or older and feel comfortable speaking about the disclosure. Your responses will be confidential. I will not share your identity or anything you say to others in a way that will identify you. With your permission, I will audio record the interview and I will delete the recording once I transcribe the interview. I will also change your name on the final thesis.

Anything you say answer will remain completely confidential, except in instances of dating violence. You can stop participating or skip questions any time you want. Please email me at cpalvar@ilstu.edu if you want to participate. Please also send along this info to others and they can contact me directly to participate. 


\section{APPENDIX D: INFORMED CONSENT}

Dear participants,

I am a graduate student under the direction of Professor Aimee Miller-Ott in the School of Communication at Illinois State University. As part of the program requirement, I am conducting my thesis to better understand how problematic messages are communicated in romantic relationships.

Your participation will involve an open-ended interview about your communication with a former romantic partner. The interview will be conducted face-to-face, over phone, or through Facetime/Skype and will take approximately one hour. The interview will be audio recorded, with your permission, to ensure accuracy of recording your words. Recordings will be erased after transcription and will not have any links to your identity in the digital files. To participate you must have been in a relationship and have had repetitive communicative interactions (written or verbal) with your partner where they hurt your feelings, made you feel bad about yourself, and/or made you feel controlled. The relationship must be a past relationship, not a current relationship.

Your participation in this study is voluntary. You may refuse to answer any question. You may skip or refuse to answer questions if you feel uncomfortable, and if you choose not to participate or to withdraw from the study at any time, there will be no penalty. Your responses are confidential - any information that might allow someone to identify you will not be disclosed, except in instances of dating violence. Your responses will be joined with those of other participants to develop themes for research presentation at conference or in publication.

As a participant, you may experience discomfort when talking about personal experiences. Participants may experience psychological or emotional pain. Participants who are distressed may contact Student Counseling Services at (309) 438-3655. Participants who are not ISU students may call the National Domestic Violence Hotline at 1-800-799-3224. Your comfort as a participant is of upmost importance. You will not be asked any questions about any physical interaction with your former partner. Respondents should not at any time disclose details about sexual or physical violence perpetrated by their former partner. As a participant, you must feel comfortable speaking about your communication with your former partner. If at any point you feel as though the interview is too uncomfortable, the interview will immediately end. You can also skip questions at any time. While your instructor may know who does or does not agree to participate in the research before grades are posted, you will not be penalized if you choose to not participate.

There is a risk of breach of confidentiality in this study. Participants may experience a risk to their reputation should a breach of confidentiality occur. To minimize this risk, participants are encouraged to choose private locations in which to answer interview questions.

We need to make you aware that in certain research studies, it is our legal and ethical responsibility to report situations of child abuse, child neglect, sexual violence, domestic violence, or any life-threatening situation, illegal activity on the ISU campus, campus-controlled 
locations, or involving ISU students to appropriate authorities. However, we are not seeking this type of information in our study nor will you be asked questions about these issues. But please be aware that if you share any of this type of information, I am required to report it.

Please direct any questions and/or comments to Dr. Aimee Miller-Ott (aeott@ilstu.edu) or myself. If you have any questions about your rights as a subject/participant in this research, or if you feel you have been placed at risk, you can contact the Research Ethics \& Compliance Office at Illinois State University at (309) 438-5527.

Sincerely,

Cimmiaron Alvarez, Graduate Student, School of Communication

Illinois State University

cpalvar@ilstu.edu 


\section{APPENDIX E: INTERVIEW PROTOCOL}

Thank you for agreeing to participate in my study on problematic communication in romantic relationships. I am going to ask you a series of open-ended questions regarding you and your former partner's communication specifically focusing on moments where your partner hurt your feelings and/or made you feel bad about yourself. If you have experienced multiple partners like this, please just choose one to answer these questions about.

First, I'm going to ask you some questions about your relationship with your former partner.

1. How did you meet?

2. How long was the relationship?

3. How would you describe the relationship? (on a scale 1 to 5 , with 5 being super close and 1 not being close at all, how close were you? Did the closeness change over time? If so, how and why?)

4. What was your living situation in regard to your partner? Did you live together?

5. Can you explain to me in the timeline of the relationship in regard to that person saying mean or hurtful things to you? Can you recall when your partner started to do or say things that made you feel bad about yourself, put you down, manipulate you, or start to use other problematic communication that hurt you or made you feel bad?

6. Looking back now or at the time, did you ever consider this relationship as abusive?

a. Follow up: What made you classify the relationship as abusive?

7. How did the relationship end?

Now I'd like to focus on your experiences with hurtful messages. You will be asked to recall specific conversations with your former partner, all within your comfort zone. Please note that I am asking for verbal messages only.

8. What are some messages or behaviors that your partner used that made you feel bad about yourself?

a. What did your partner say or write specifically?

b. How was it said?

c. What was the context of this communication?

d. (if needing follow-up for clarity: These messages might be things they said or things they did when talking to you like the way they said things or their facial expressions or other nonverbal)

9. Were any of these messages worded in a way that made them seem positive or polite but then still hurt you or made you feel bad?

a. Can you give a specific example?

b. When communicating with your partner, did you prefer direct message or polite messages?

10. What was the typical tone your partner used when communicating these messages?

a. Did this make the message hurt more or less?

11. Were there messages you had difficulty interpreting? For example, did the message seem to say one thing but actually communicate another? 
12. Can you recall messages that you felt were hurtful that your partner told you that you took the wrong way or that they didn't mean it that way?

13. How did you view these messages at the time they were sent?

a. Have you changed how you view them since they were sent?

14. How did your perceptions of your partner change based on these messages?

15. What do you think your partner was hoping to accomplish with these messages?

a. Do you think your partner was aware of what they were actually communicating?

16. When did these messages or communication instances typically take place? Such as, were you alone? Were you around other people?

17. Did any of these messages ever occur when you were around another individual, even if they did not normally occur in public?

a. If you were around someone, who were you with?

b. Did the other person or people respond to the message? If so, what did they say or do?

c. How did you make sense of this public message?

18. How did you respond to your partner's messages?

a. Can you give a specific example?

19. Did your partner ever deny that they used these hurtful messages? Did they ever try to make you believe that they said or meant something different?

20. Now that you are out of the relationship, do you view this relationship and your partner's communication differently? If so, how?

\section{Now I'd like to focus on your communication experiences following the problematic messages of your partner.}

21. How have these messages from your former partner changed how you communicate with peers? How have these messages changed how you communicate with other romantic partners?

22. When engaging in your own messages that might hurt someone or make them feel bad about themselves, have you changed how you communicate this based on your experience with your former partner? If so, how?

23. Has this experience changed how you react and respond to messages of criticism?

What suggestions would you have for someone who is in a romantic relationship with someone who might say things that make them feel bad about themselves or hurt them?

\section{Is there anything else you would like to share concerning your former partner?}




\section{APPENDIX F: DEMOGRAPHIC SURVEY}

\section{Prior to your interview, please fill out this survey about you and your former partner.}

1. What is your age?

2. What is your sex?

3. What is your race or ethnicity?

4. What is your gender?

5. What is your sexuality?

6. How long ago was your relationship with your partner?

7. What was your age at the time of the relationship?

8. What was your partner's age?

9. What was your partner's gender?

10. What was your partner's race or ethnicity?

11. What was your partner's sexuality? 